\title{
Cereblon versus VHL: Hijacking E3 ligases against each other using PROTACs
}

\author{
Miriam Girardini $^{\mathrm{a}, \mathrm{b}}$, Chiara Maniaci ${ }^{\mathrm{a}, \mathrm{b}, \mathrm{c}}$, Scott J. Hughes ${ }^{\mathrm{a}, \mathrm{b}}$, Andrea Testa ${ }^{\mathrm{a}}$, Alessio Ciulli ${ }^{\mathrm{a}, *}$ \\ ${ }^{a}$ Division of Biological Chemistry and Drug Discovery, School of Life Sciences, University of Dundee, Dow Street, Dundee DD1 5EH, Scotland, United Kingdom
}

\section{A R T I C L E I N F O}

\section{Keywords:}

PROTACs

E3 ubiquitin ligases

Targeted protein degradation

von Hippel-Lindau protein

Cereblon

\begin{abstract}
A B S T R A C T
The von Hippel-Lindau (VHL) and cereblon (CRBN) proteins are substrate recognition subunits of two ubiquitously expressed and biologically important Cullin RING E3 ubiquitin ligase complexes. VHL and CRBN are also the two most popular E3 ligases being recruited by bifunctional Proteolysis-targeting chimeras (PROTACs) to induce ubiquitination and subsequent proteasomal degradation of a target protein. Using homo-PROTACs, VHL and CRBN have been independently dimerized to induce their own degradation. Here we report the design, synthesis and cellular activity of VHL-CRBN hetero-dimerizing PROTACs featuring diverse conjugation patterns. We found that the most active compound 14a induced potent, rapid and profound preferential degradation of CRBN over VHL in cancer cell lines. At lower concentrations, weaker degradation of VHL was instead observed. This work demonstrates proof of concept of designing PROTACs to hijack different E3 ligases against each other, and highlights a powerful and generalizable proximity-induced strategy to achieve E3 ligase knockdown.
\end{abstract}

\section{Introduction}

Targeting proteins for degradation by hijacking the ubiquitin-proteasome system with small molecules is a powerful modality of intervention into biology, and an emerging therapeutic strategy. ${ }^{1-4} \mathrm{~A}$ primary approach to targeted protein degradation involves the design of PROTACs (PROteolysis-Targeting Chimeras). PROTACs are bifunctional compounds that form a ternary complex with a target protein of interest and an E3 ubiquitin ligase, such that the target protein is ubiquitinated by the hijacked E3 ligase and subsequently degraded by the proteasome. ${ }^{5,6}$ PROTACs are defined by a catalytic, sub-stoichiometric mode of action that can allow for rapid, profound and selective target depletion inside cells, and an extended duration of action, also in vivo. ${ }^{7-10}$ Because their mode of action differs from that of conventional inhibitors, the concentrations at which PROTACs exert degradation activity are often much lower than expected based on their dissociation constants with the target protein. ${ }^{11-14}$ Furthermore, PROTAC's selectivity can be greater than the binding selectivity of the ligands alone, allowing to discriminate between highly similar proteins or isoforms in ways that are not possible with occupancy-based inhibitors. . $^{8,11,12,15-17}$ Within the past four years, potent and selective PROTACs have been designed to hijack either the von Hippel-Lindau (VHL) or cereblon (CRBN) E3 ligase against a target protein of interest. ${ }^{18,19}$ Targets that have been shown to be degraded by PROTACs include members of bromodomain-containing proteins such as the BET proteins (Brd2, Brd3 and Brd4), ${ }^{7-9,14,15,17,20,21}$ amongst other epigenetic protein classes; ${ }^{22-26}$ protein kinases; ${ }^{10,12,27-31}$ as well as non-bromodomain and non-kinase target proteins. ${ }^{32-35}$ Recent progress in understanding principles of PROTAC mode of action, and demonstration of applicability across different target classes, suggest that PROTACs have the potential to target new protein families, including proteins that are difficult to block using current approaches. Clinical validation of small molecules inducing protein degradation is provided by recent discoveries on the molecular mechanism of thalidomide and related clinical anticancer immunomodulatory drugs (IMiDs) such as lenalidomide and pomalidomide, which induce the proteasomal-dependent degradation of cancer-driving proteins. ${ }^{36,37}$ More recently, a PROTAC compound (ARV-110) that targets the androgen receptor for degradation has been announced as a clinical candidate. ${ }^{38}$

E3 ubiquitin ligases are key players in the ubiquitin-proteasome pathway because they catalyse ubiquitination of substrate proteins. ${ }^{39-41}$ As important regulators of cellular ubiquitination, E3 ligases are emerging as attractive drug targets, particularly in cancer. ${ }^{42-44}$ However, E3 ligases have proven difficult to target using small molecule inhibitors. So far only few high-quality inhibitors have been developed, mainly against the ligases MDM2, ${ }^{45}$ VHL, ${ }^{46}$ and IAPs. ${ }^{47}$ E3

\footnotetext{
* Corresponding author.

E-mail address: a.ciulli@dundee.ac.uk (A. Ciulli).

${ }^{\mathrm{b}}$ These authors contributed equally to this work.

${ }^{\mathrm{c}}$ Current address: University of Oxford, Chemistry Research Laboratory, 12 Mansfield Road, Oxford OX1 3TA, United Kingdom.
} 


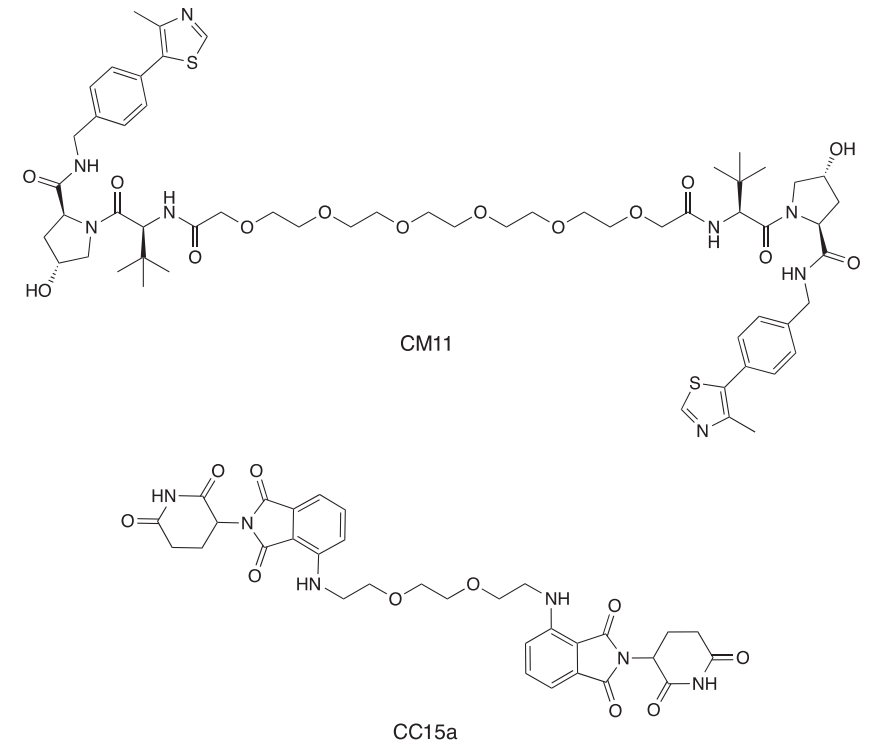

Figure 1. Previously published homo-PROTACs CM11 and CC15a, which induce self-degradation of the E3 ligases VHL and CRBN, respectively. CM11 and CC15a are symmetric homodimers of VHL ligand and CRBN ligand pomalidomide, respectively.

ligases lack deep binding sites to accommodate endogenous small-molecule cofactors or substrates, as is the case for ATP in protein kinases. ${ }^{48}$ Targeting E3 ligases therefore requires disruption (or modulation) of

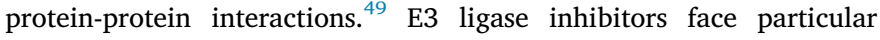
challenges: first, the difficulty to compete with high-affinity endogenous substrates, which increase in level as a result of E3 blockade; ${ }^{50}$ and second, the observation that small molecules that bind to E3 ligases may modulate the surface of the targeted E3 in such a way that new substrate proteins are recruited for degradation, as shown for the E3 ligases CRBN, ${ }^{37,51,52}$ and DCAF15. ${ }^{53,54}$

We hypothesized that the E3 ligases themselves might be hijacked against one another using a PROTAC approach, thus inducing E3 ligase degradation as opposed to E3 blockade. In 2017, we disclosed the first report of a small molecule dimerizer of an E3 ligase as a means to induce its own degradation, an approach that we called "homoPROTAC". ${ }^{11}$ We designed bifunctional molecules made up of the same ligand for the ubiquitously expressed VHL protein, connected via a linker, that would induce VHL dimerization as the key step to trigger VHL ubiquitination and subsequent degradation. The best degrader, the symmetric homo-PROTAC CM11 (Figure 1), dimerized VHL in vitro with high avidity (cooperativity) of $\sim 20$-fold, leading to potent, complete and prolonged degradation of VHL in different cell lines. With CM11, we confirmed the hypothesized mechanism and qualified a novel chemical probe degrader for VHL. ${ }^{11}$ Subsequently, the same idea was applied by Krönke, Gütschow and co-workers, who reported homoPROTACs for the CRBN ligase, and showed compound 15a (CC15a in Figure 1) to be the most active compound. ${ }^{55}$ As an extension of our homo-PROTAC approach, we envisaged that two different E3 ligases could be brought together using hetero-bifunctional PROTACs made of a ligand handle for one ligase and another handle for a different ligase. ${ }^{56}$ We hypothesized that with such compounds the two E3 ligases might be hijacked against one another, leading to two potential scenarios: 1) both ligases being degraded in cell; 2) one of the two being preferentially degraded - resulting in one ligase 'winning' over the other one. In the present study, we describe the design, synthesis and cellular activity of VHL-CRBN heterodimerizing PROTACs, and interrogate the outcome of hijacking these two E3 ligases against each other.<smiles>Nc1cccc2c1C(=O)N([C@@H]1CCC(=O)NC1=O)C2=O</smiles>

Pomalidomide

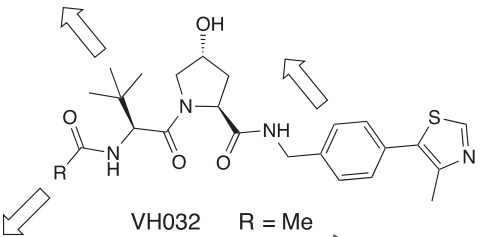

$\mathrm{VH} 101 \mathrm{R}=\mathrm{P}_{\mathrm{F}}$

VH298 R $=P_{\mathrm{CN}}$<smiles>Cc1ncsc1-c1ccc(S(C)(=O)=O)c(OCCCNc2cccc3c2C(=O)N([C@@H]2CCC(=O)NC2=O)C3=O)c1</smiles>

Series 3

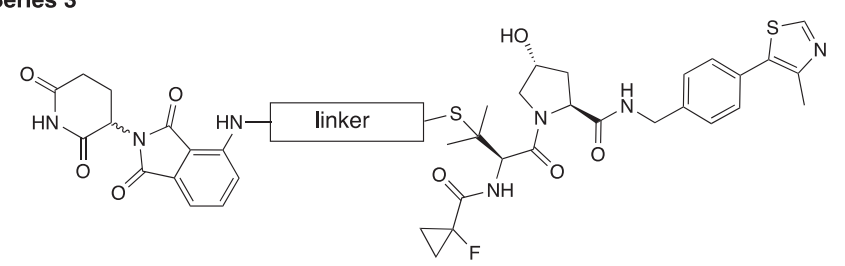

Figure 2. Design of VHL-CRBN conjugates explored in this work.

\section{Results and discussion}

\subsection{Design of a library of CRBN-VHL PROTACs}

In order to better explore potentially different relative orientations between the two E3 ligases, we began by designing three series of heterodimerizers characterized by different attachment points on the VHL ligase handle (Figure 2): 1) out of the terminal acetyl group of VHL ligand VH032. ${ }^{50,57}$ Amidation of a terminal tert-Leu of the VHL ligand (compound 1, Figure 3 ) is a widely-explored conjugation strategy for

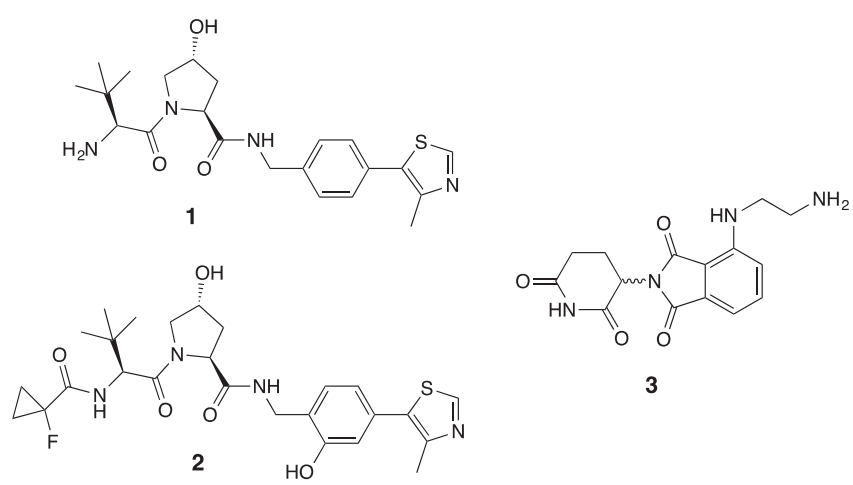

Figure 3. Chemical structure of VHL ligands $\mathbf{1}$ and 2, and CRBN ligand 3. 
PROTACs, including our homo-PROTAC CM11; ${ }^{11}$ 2) via a phenolic substituent out of VH101, a more potent VHL ligand in which the cyano-cyclopropyl group of chemical probe VH298 is replaced with a fluoro-cyclopropyl group, as shown in our published SAR of VHL ligands. ${ }^{46}$ Successful conjugation of this optimized VHL ligand (compound 2, Figure 3) was recently reported by our laboratory in Brd9 degrader VZ185; ${ }^{23}$ 3) via a thioether linkage out of the tert-butyl group of the VHL ligand, in which the tert-Leu group is replaced with a penicillamine group, as we previously incorporated in Brd4-selective degrader AT $1 .{ }^{15}$ Unlike AT1, in which the VHL ligand handle bears a terminal acetyl group, here we decided to keep the terminal fluorocyclopropyl group as in VH101. As CRBN handle, we chose pomalidomide because of its greater cellular stability compared to other IMiDs. ${ }^{58}$ To derivatize pomalidomide we appended an ethylenediamine spacer out of the phthalimide ring (compound 3, Figure 3), to provide a synthetically convenient attachment point for amide conjugation of a linker. ${ }^{23,29}$

The linker plays a crucial role in PROTAC design and activity. Small changes in both length and physicochemical nature e.g. alkylic versus polyethylene glycol (PEG) as well as mixtures thereof, are known to impact degradation activity and selectivity in often unpredictable ways. ${ }^{21,22,31}$ We therefore decided to explore different linkers, focusing on varying lengths and ratio between carbon and oxygen atoms, as we and others have found that these modifications can have a profound impact on PROTAC structure-activity relationships. ${ }^{21-23,31}$ As a result, the designed compounds explore diversity in the derivatization point, linker length and chemical properties.

\subsection{First series of PROTACs.}

The first series of VHL-CRBN PROTACs (Figure 2) comprises compounds $7 \mathbf{a}, \mathbf{b}$ and $14 \mathbf{a}-\mathbf{e}$. Compounds $\mathbf{6 a}$ and $\mathbf{6 b}$, bearing respectively a 2 and 4 PEG unit linkers, were synthesized as previously reported. ${ }^{11}$ Briefly, triethylene or pentaethylene glycol were first converted to monobenzyl ethers and then reacted with tert-butyl bromoacetate under biphasic conditions to yield linkers $\mathbf{4 a - b}$ in good yields (SI Scheme 1). After deprotection of the benzyl group by catalytic hydrogenation, the primary alcohol was oxidised to carboxylic acid and subsequently coupled with VHL ligand $\mathbf{1}$, as described, ${ }^{11}$ to afford compounds $\mathbf{6 a - b}$ (SI Scheme1). Deprotection of the tert-butyl group in acidic condition followed by coupling with CRBN ligand 3 afforded the final PROTACs $7 \mathbf{a}-\mathbf{b}$ in $95 \%$ and $84 \%$ yield, respectively (Scheme 1 ).

For the synthesis of PROTACs 14a-e, symmetric linkers 12a-e bearing two terminal carboxylate groups were designed with different length and composition. Compounds 12a-e were prepared starting from the corresponding diols 10a-e. Diol 10b-e were commercially available, instead 10a was synthesized in house by adapting a previously reported method. ${ }^{31}$ Briefly, 10a was obtained after a nucleophilic substitution reaction between the tosyl derivative of a monobenzyl protected 1,5 pentadiol and ethylene glycol in a 2:1 ratio, followed by deprotection of the benzyl group by catalytic hydrogenation (SI Scheme 2). Nucleophilic substitution in phase transfer catalysis of diols 10a-e followed by deprotection in acidic conditions, based on our previously reported synthetic route, ${ }^{11}$ delivered compounds 12a-e (SI Scheme 3).
Subsequently, mono $N$-hydroxysuccinamide ester derivatives of 12a-e, obtained via reaction with $N$-hydroxysuccinimide (NHS) and $N, N$-dicyclohexylcarbodiimide (DCC), were reacted with CRBN ligand 3 in a 2:1 ratio to afford 13a-e (Scheme 2). The NHS activation of the linkers was required in order to better control the reaction and to reduce the formation of 2:1 conjugates between 3 and linkers. After removal of dicyclohexylurea (DCU) side product by filtration, the 1:1 conjugates 13a-e were subsequently coupled with $\mathbf{1}$ to obtain the final PROTACs 14a-e in 42-62\% yields (Scheme 2 ).

\subsection{Second series of PROTACs.}

Linkers for the second PROTAC series (Figure 2) were designed to contain a carboxylic group protected as tert-butyl ester on one side and a leaving group on the other side, which could be coupled with the phenol group on VHL ligand 2. Linkers 15a-b were synthesized as previously reported, ${ }^{31}$ and their alkyl iodide derivatives 16 a-b were prepared by reaction of the alcohol group with $\mathrm{Ph}_{3} \mathrm{P} \cdot \mathrm{I}_{2}$ reagent prepared in situ (Scheme 3). Ligand $\mathbf{2}$ was reacted with compounds $\mathbf{1 6} \mathbf{a}-\mathbf{b}$ and commercially available methyl 5-bromobutanoate (16c) in the presence of $\mathrm{K}_{2} \mathrm{CO}_{3}$ to afford 17a-c, respectively, in good yields. Final PROTACs 18a-c were obtained upon deprotection of either the tert-butyl group, in case of $17 \mathbf{a}-\mathbf{b}$, or the methyl group for $17 \mathbf{c}$, and subsequent amide coupling with CRBN ligand 3, using (1-cyano-2-ethoxy-2-oxoethylidenaminooxy)dimethylamino-morpholino-carbenium hexafluorophosphate (COMU) as coupling reagent and $N, N$-diisopropylethylamine (DIPEA) as base (Scheme 3).

\subsection{Third series of PROTACs.}

For the synthesis of this series of PROTACs, VHL ligand 20 was synthesized in two steps: a first coupling reaction of previously reported compound 19 (ref. ${ }^{15}$ ) with 1-fluorocyclopropane-1-carboxylic acid, followed by deprotection of the thiol moiety (Scheme 4). Linkers 16a-c were connected to $\mathbf{2 0}$ via a sulphur alkylation reaction in the presence of DBU as the base. Deprotection of the tert-butyl ester group of 21a-c, and subsequent coupling with 3 under the same conditions described above, delivered the final compounds 22a-c in good yields (Scheme 4).

\subsection{Evaluation of PROTAC cellular activity.}

To profile the degradation activity of our panel of PROTACs, VHL and CBRN protein levels in HeLa cells were quantified by western blot analysis following a $4 \mathrm{~h}$ treatment with $1 \mu \mathrm{M}$ compounds, using CM11 and CC15a as positive controls for VHL and CRBN degradation, respectively (Figure 4). Interestingly, we observed significant degradation of CRBN with a few compounds, while no significant degradation of VHL was observed with any of the compounds tested. The most profound CRBN degradation was observed with PROTAC 14a (64\% protein degradation, as quantified by western blot), followed by compound $\mathbf{1 8 b}$ which induced CRBN degradation to a lower extent (54\% degradation). The same screen was conducted in a different cell line (HEK293), confirming 14a as the most potent compound at inducing CRBN degradation (data not shown). To provide a more stringent screen the

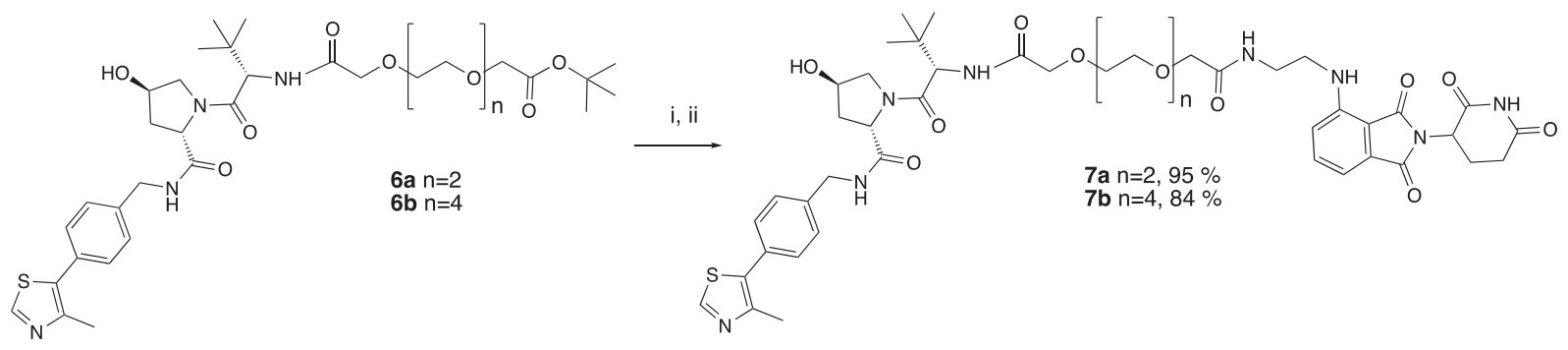

Scheme 1. Synthesis of PROTACs 7a-b. Conditions: i. 1:1 TFA/DCM, r.t.; ii. HATU, HOAt, 3, DIPEA, DMF, r.t. 


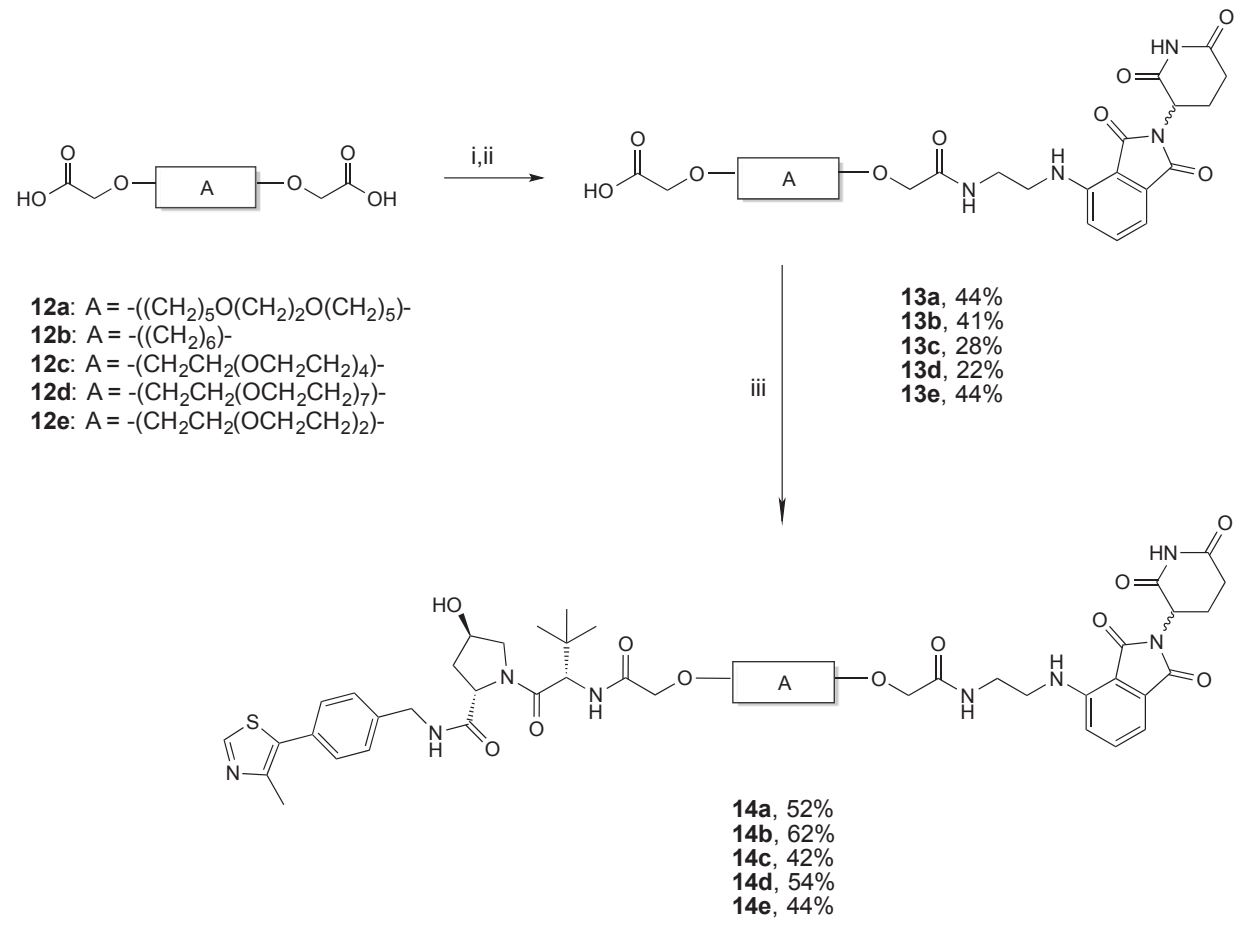

Scheme 2. Synthesis of PROTACs 14a-e. Reagents and conditions: i. NHS, DCC, DCM, r.t, overnight; ii. 3, DIPEA, DMF, r.t; iii. 1, COMU, DIPEA, DMF.

same experiment was conducted by testing compounds at $10 \mathrm{nM}$ in HeLa cells (Figure S1). The purpose of this experiment was to exclude the possibility of dismissing any potent compound as a false negative potentially due to the "hook effect" characteristic of bivalent molecules: whereby unproductive binary complexes preferentially form at high PROTAC concentration, which compete with and eventually suppress the formation of a productive ternary complex. ${ }^{9}$ PROTAC 14 a induced less CRBN degradation (19\% protein degradation) at $10 \mathrm{nM}$ compared to $1 \mu \mathrm{M}$, as expected. Importantly, CRBN protein levels remaining after treatment at $10 \mathrm{nM}$ were not significantly lower than the levels remaining after the same treatment at $1 \mu \mathrm{M}$ (cf. Figure S1 with Figure 4), making it unlikely that any of the compounds might be false negatives due to a hook effect. Interestingly, at this lower concentration some compounds appeared to induce up to $50 \%$ degradation of pVHL30 (Figure S1). This suggests that depending on the concentration being used this class of compounds could preferentially induced the depletion of one ligase over the other.

Encouraged by the promising and consistent degradation of CRBN observed with PROTAC 14a, we selected this compound for further characterization. We next profiled the concentration- and time-dependent activity of 14a in both HeLa (Figure 5) and HEK293 cells (Figure S2). Compound 14a degraded CRBN with a half-degrading concentration $\mathrm{DC}_{50}$ (i.e. the concentration causing $50 \%$ reduction of protein level relative to vehicle) of $200 \mathrm{nM}$, and reached a maximal degradation $\left(D_{\max }\right)$ of $75 \%$ after $4 \mathrm{~h}$ treatment with $1 \mu \mathrm{M}$. A hook effect was observed above $1 \mu \mathrm{M}$, indicating that 14a preferentially forms the 1:1

$$
\begin{array}{ll}
\text { 15a: } A=-\left(\mathrm{OCH}_{2} \mathrm{CH}_{2}\right)_{2} \mathrm{OCH}_{2} ; \mathrm{R}_{1}=t-\mathrm{Bu} & 16 \mathrm{a}: \mathrm{A}=-\left(\mathrm{OCH}_{2} \mathrm{CH}_{2}\right)_{2} \mathrm{OCH}_{2} ; \mathrm{R}_{1} \\
\text { 15b: } \mathrm{A}=-\left(\mathrm{OCH}_{2} \mathrm{CH}_{2}\right)_{4} \mathrm{OCH}_{2}-; \mathrm{R}_{1}=t-\mathrm{Bu} & 16 \mathrm{~b}: \mathrm{A}=-\left(\mathrm{OCH}_{2} \mathrm{CH}_{2}\right)_{4} \mathrm{OCH}_{2} ; \mathrm{R}_{1}
\end{array}
$$

16a: $A=-\left(\mathrm{OCH}_{2} \mathrm{CH}_{2}\right)_{2} \mathrm{OCH}_{2}-; \mathrm{R}_{1}=t-\mathrm{Bu} ; \mathrm{R}_{2}=\mathrm{I}, 79 \%$ 16b: $\mathrm{A}=-\left(\mathrm{OCH}_{2} \mathrm{CH}_{2}\right)_{4} \mathrm{OCH}_{2}-; \mathrm{R}_{1}=t-\mathrm{Bu} ; \mathrm{R}_{2}=1,81 \%$ 16c: $\mathrm{A}=-\mathrm{CH}_{2} \mathrm{CH}_{2}-; \mathrm{R}_{1}=\mathrm{Me} ; \mathrm{R}_{2}=\mathrm{Br}$<smiles>Nc1cccc2c1C(=O)N([C@H]1CCC(=O)NC1=O)C2=O</smiles><smiles>Cc1ncsc1-c1ccc(CNC(=O)C2C[C@@H](O)CN2C(=O)C(NC(=O)C2(F)CC2)C(C)(C)C)c(OCCC2CC3CCCC2C3)c1</smiles>

$18 \mathrm{a}, 23 \%$

$18 \mathrm{c}, 22 \%$

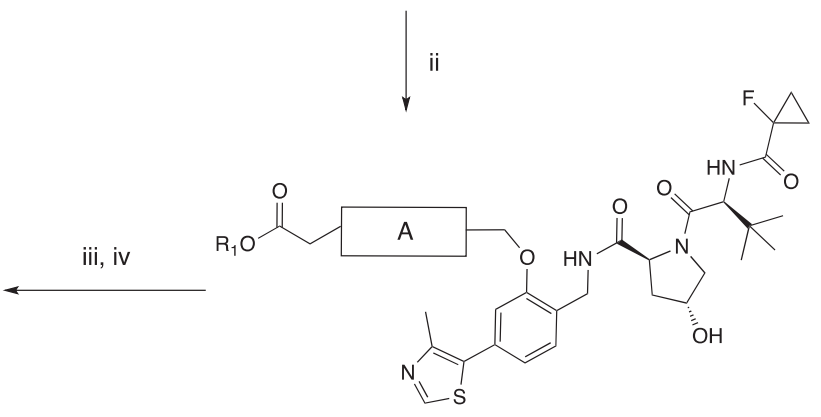

$17 a, 22 \%$

$17 \mathrm{~b}, 48 \%$

Scheme 3. Synthesis of PROTACs 18a-c. Reagents and conditions: i. Iodine, triphenylphosphine, imidazole, DCM, $0{ }^{\circ} \mathrm{C}$; ii. $2, \mathrm{~K}_{2} \mathrm{CO}_{3}, \mathrm{DMF}^{\circ} 70^{\circ} \mathrm{C}$, overnight, iii. for tert-butyl deprotection: 1:1 TFA/DCM; for the methyl deprotection: LiOH in water/THF, 2 h, r.t; iv. COMU, 3, DIPEA, DMF, r.t. 
<smiles>[3H]SC(C)(C)C(N)C(=O)N1C[C@H](O)C[C@H]1C(=O)NCc1ccc(-c2scnc2C)cc1</smiles>

19<smiles>Cc1ncsc1-c1ccc(CNC(=O)[C@@H]2C[C@H](O)CN2C(=O)C(NC(=O)C2(F)CC2)C(C)(C)S)cc1</smiles>

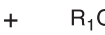<smiles>[R6]CCCCCCC(=O)O</smiles>

16a: $\mathrm{A}=-\left(\mathrm{OCH}_{2} \mathrm{CH}_{2}\right)_{2} \mathrm{OCH}_{2}-; \mathrm{R}_{1}=t-\mathrm{Bu} ; \mathrm{R}_{2}=\mathrm{I}$ 16b: $\mathrm{A}=-\left(\mathrm{OCH}_{2} \mathrm{CH}_{2}\right)_{4} \mathrm{OCH}_{2}-; \mathrm{R}_{1}=t-\mathrm{Bu} ; \mathrm{R}_{2}=\mathrm{I}$ 16c: $\mathrm{A}=-\mathrm{CH}_{2} \mathrm{CH}_{2} ; \mathrm{R}_{1}=\mathrm{Me} ; \mathrm{R}_{2}=\mathrm{Br}$

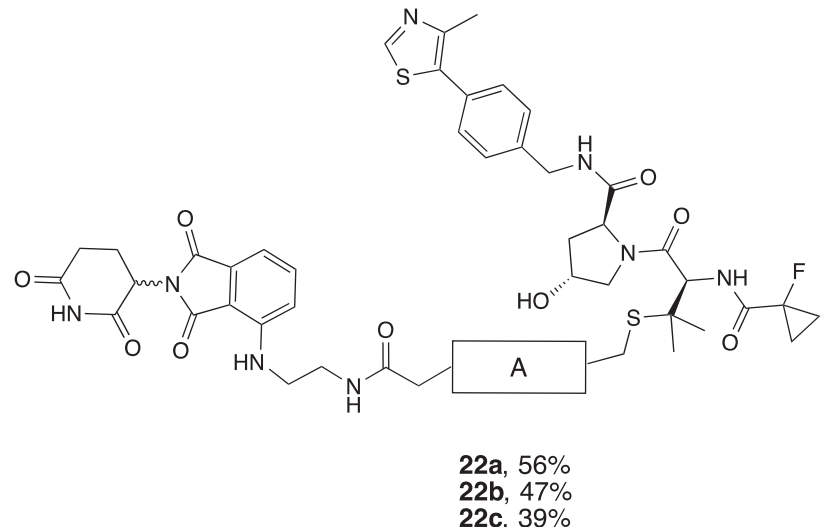

iii

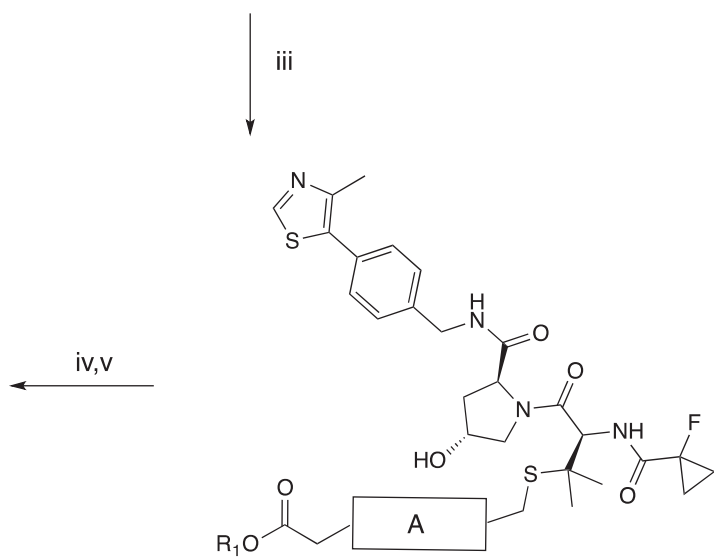

21a, $46 \%$

21b, $66 \%$

21c, $67 \%$

Scheme 4. Synthesis of PROTACs 22a-c. Reagents and conditions: i. 1-fluorocyclopropane-1-carboxylic acid, HATU, HOAt, DIPEA, DMF, r.t., 30 min; ii. TIPS, TFA, DCM, r.t., 2 h; iii. DBU, DMF, $0^{\circ} \mathrm{C}$ to r.t, 4 h; iv. For tert-butyl deprotection: 1:1 TFA/DCM; for the methyl deprotection: LiOH in water/THF $2 \mathrm{~h}$, r.t; v. COMU, 3 , DIPEA in DMF, r.t.

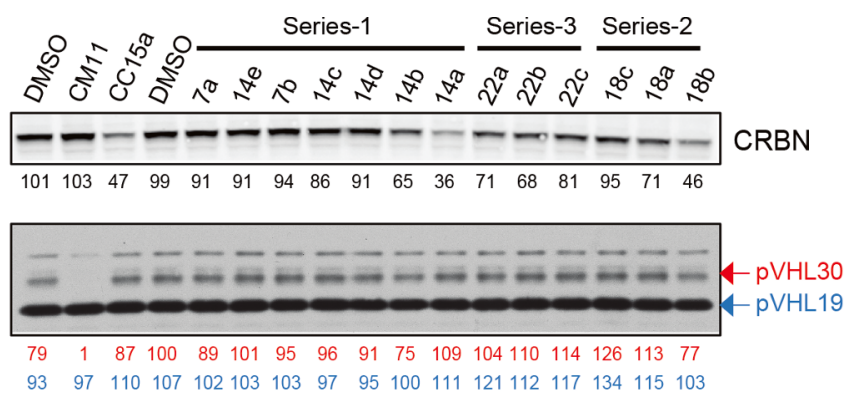

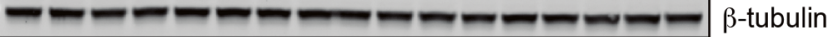

Figure 4. Screening of VHL-CRBN hetero-PROTACs. Western blot analysis of CRBN and VHL levels following $4 \mathrm{~h}$ treatment of HeLa cells with $1 \mu \mathrm{M}$ compound. Values reported below each lane indicate protein abundance relative to the average $0.1 \%$ DMSO vehicle, and normalized for loading control.

species (i.e. acts as inhibitor) at higher concentrations. Very similar degradation profile and comparable $\mathrm{DC}_{50}$ and $\mathrm{D}_{\max }$ were found for $14 \mathrm{a}$ in HEK293 (Figure S2). Again, some concentration-dependent depletion of pVHL30 was seen at the lower end of the concentration range (5-50 nM) in HeLa (Figure 5). However interestingly this effect was not observed in HEK293 (Figure S2). From the time-course data, compound 14a was able to induce rapid degradation, with $>50 \%$ CRBN levels relative to control depleted already after $1 \mathrm{~h}$; maximal degradation > $80 \%$ was attained after $8 \mathrm{~h}$ (Figure 5). The 14a-induced degradation of CRBN was found to be even faster in HEK293, with $>80 \%$ protein already depleted after $1 \mathrm{~h}$, and 98\% degradation achieved after $8 \mathrm{~h}$ (Figure S2). Once again the compound displayed selectivity for CRBN, as there was no appreciable VHL degradation at $1 \mu \mathrm{M}$ over the time points tested in either cell line (Figure 5 and Figure S2).

\section{Discussion}

We described dually targeting CRBN-VHL PROTACs, developed with the aim of investigating the relative ability of CRBN and VHL E3 ligase to induce degradation of one other. Among the three series of compounds developed, we observed preferential degradation of one ligase i.e. CRBN over the other one (VHL) with some of the compounds from two of the series. The most potent PROTAC, compound 14a, induced CRBN degradation with high potency $\left(\mathrm{DC}_{50}\right.$ of $\left.200 \mathrm{nM}\right)$ and to profound levels ( $\mathrm{D}_{\max }$ of up to $98 \%$ ) and rapidly (within $1 \mathrm{~h}$ of treatment). Further structure-activity relationships could help to better understand and improve the already high potency and efficiency of CRBN degradation achieved with 14a.

Our data thus suggests that VHL can 'win the battle' with CRBN when the two ligases are brought together by a PROTAC. Future mechanistic studies are warranted to attempt to elucidate the contributors for this preferential unilateral outcome of our 'double-hijacking' approach. We also cannot exclude that different combinations of conjugation patterns (via different attachment points for example) and linker lengths and structures of CRBN-VHL PROTACs might be able to discriminate different relative orientation of the ternary complex in such a way that the outcome might become reverse, i.e. VHL being preferentially degraded over CRBN - a hypothesis that will be tested in future work. In this regard, it is interesting to note that minor concentration-dependent depletion of pVHL30 was observed at the lower end of the concentration range (5-50 nM) in HeLa (Figure 5) as well as in the screen at lower compound concentration ( $10 \mathrm{nM}$, Figure S2). pVHL30 is the VHL isoform that is preferentially degraded by the homoPROTAC CM11. ${ }^{11}$ No observable PROTAC-induced degradation of pVHL19 was instead observed with any of our compounds, consistent with the cellular outcome observed with CM11. These observations together suggest an enticing possibility that differential ligase degradation might apply at distinct ranges of concentration of CRBN-VHL dimerizers. Differential absolute concentration between the two E3 
A

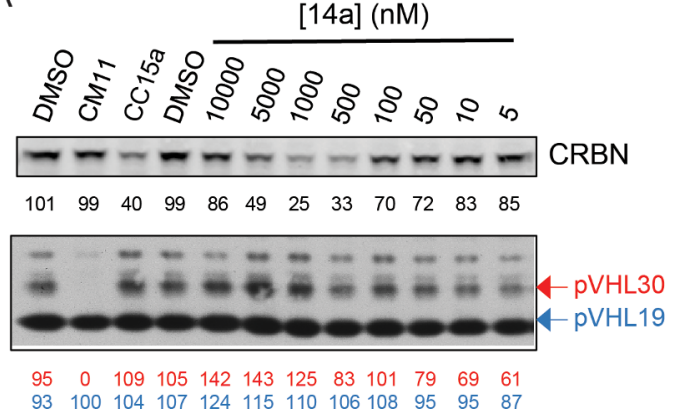

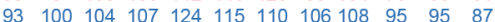
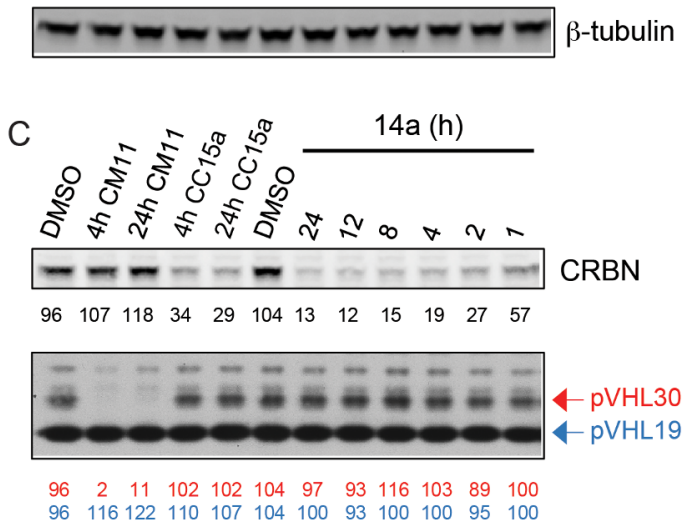

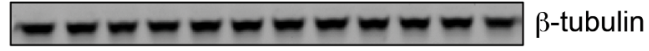

B

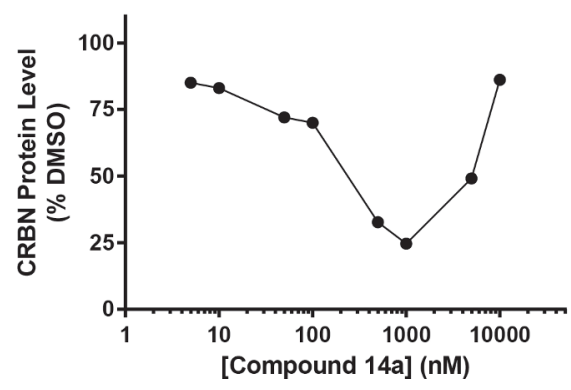

$\mathrm{DC}_{50} 14 \mathbf{a}(4 \mathrm{~h})=200 \mathrm{nM}$

D

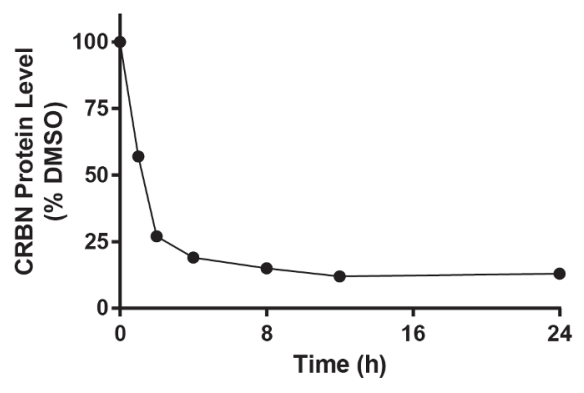

Apparent half-life of CRBN $=0.9 \mathrm{~h}$
Figure 5. Compound 14a induces rapid depletion of CRBN, but not of VHL. (A) Western blot analysis of CRBN and VHL levels following $4 \mathrm{~h}$ treatment of HeLa cells with the indicated concentrations of 14a. (B) Quantification of CRBN levels following concentration-dependent assessment. (C) Western blot analysis of CRBN and VHL levels following treatment of HeLa cells with $1 \mu \mathrm{M} \mathrm{14a}$ for the indicated time points. (D) Quantification of CRBN levels following time-dependent assessment. Values reported below each lane indicate protein abundance relative to the average $0.1 \%$ DMSO vehicle, and normalized for loading control. $\mathrm{DC}_{50}$ and half-lives were determined as described in the Experimental Section. ligases, and/or differential binding affinities of each end of the bivalent molecule for its respective ligase, are likely to be amongst the contributing factors that could effectively skew the hook effect towards one ligase versus the other one depending on the PROTAC concentration, ultimately imparting differential protein degradation outcomes. Such an effect could be of relevance in a broader context for other E3 ligase pairs. It is noteworthy that a recent study reported MDM2 PROTAC degraders, designed by linking an MDM2 inhibitor via either a thalidomide-based CRBN ligand or a VHL ligand. ${ }^{59}$ Potent and selective PROTAC-induced degradation of MDM2 was observed for the CRBNMDM2 heterodimers. However notably, protein level of the hijacked CRBN or VHL ligases were not monitored. ${ }^{59}$ Hetero-bifunctional VHLCRBN PROTACs were also disclosed in a study recently published by Steinebach et al. ${ }^{60}$ Preferential degradation of CRBN over VHL was also observed by Steinebach et al., with their most potent compound (CRBN6-5-5-VHL) being a conjugate of pomalidomide and VHL ligand via the terminal acetyl group, as with 14a, albeit with a different linker structure. $^{60}$

Our study provides proof of principle for dimerizing two different E3 ligases as a novel approach to inducing one ligase to degrade the other one. The outcome of 'ligase versus ligase' PROTAC-mediated activity might be unpredictable a priori, but could reveal a new mechanism for proximity-mediated hijacking between E3 ligases. Future work is warranted to interrogate many more combinations of E3 ligases and hetero-dimerizer compounds to bring E3 ligases together as a mechanism to induce their intracellular degradation. Given the number of E3 ligases predicted to function in cells (up to 600) this approach could speed up our ability to chemically intervene on E3 ligase themselves using targeted protein degradation, with both biological and therapeutic benefits.

\section{Experimental Section}

\subsection{Chemistry}

Commercially available chemicals were purchased from Apollo Scientific, Sigma-Aldrich, Fluorochem, or Manchester Organics and used without any further purification. Compounds $\mathbf{1},{ }^{8} \mathbf{2},{ }^{23} \mathbf{3},{ }^{23} \mathbf{6 b},{ }^{11}$ 12e, ${ }^{11}$ and $19,{ }^{15}$ were prepared as previously described.

All reactions were carried out using anhydrous solvents. Analytical thin-layer chromatography (TLC) was performed on precoated TLC plates (layer $0.20 \mathrm{~mm}$ silica gel 60 with fluorescent indicator (UV 254: Merck)). The TLC plates were air-dried and revealed under UV lamp $(254 / 365 \mathrm{~nm})$ or permanganate stain. Flash column chromatography was performed using prepacked silica gel cartridges (230-400 mesh, 40-63 mm; SiliCycle) using a Teledyne ISCO Combiflash Companion or Combiflash Retrieve using the solvent mixtures stated for each synthesis as mobile phase. Preparative HPLC was performed on a Gilson preparative HPLC with a Waters X-Bridge C18 column $(100 \mathrm{~mm} \times 19 \mathrm{~mm}$; $5 \mu \mathrm{m}$ particle size, flow rate $25 \mathrm{~mL} / \mathrm{min}$ ). Liquid chromatography-mass spectrometry (LC-MS) analyses were performed with either an Agilent HPLC 1100 series connected to a Bruker Daltonics MicroTOF or an Agilent Technologies 1200 series HPLC connected to an Agilent Technologies 6130 quadrupole spectrometer. For LC-MS the analytical cololum used was a Waters X-bridge C18 column $(50 \mathrm{~mm} \times 2.1 \mathrm{~mm} \times 3.5 \mathrm{~mm}$ particle size $)$; flow rate, $0.5 \mathrm{~mL} / \mathrm{min}$ with a mobile phase of water $/ \mathrm{MeCN}+0.01 \% \mathrm{NH}_{4} \mathrm{OH}$ (basic analytical method) or water/MeCN $+0.01 \% \mathrm{HCOOH}$ (acidic analytical method); $95 / 5$ water/MeCN was initially held for $0.5 \mathrm{~min}$ followed by a linear gradient from $95 / 5$ to $5 / 95$ water/MeCN over 3.5 min which was then held for $2 \mathrm{~min}$. The purity of all the compounds was evaluated using the 
analytical LC-MS system described before, and purity was > 95\%. ${ }^{1} \mathrm{H}$ NMR and ${ }^{13} \mathrm{C}$ NMR spectra were recorded on a Bruker Avance II 500 spectrometer $\left({ }^{1} \mathrm{H}\right.$ at $500.1 \mathrm{MHz},{ }^{13} \mathrm{C}$ at $\left.125.8 \mathrm{MHz}\right)$ or on a Bruker DPX400 spectrometer $\left({ }^{1} \mathrm{H}\right.$ at $400.1 \mathrm{MHz},{ }^{13} \mathrm{C}$ at $\left.101 \mathrm{MHz}\right)$. Chemical shifts $(\delta)$ are expressed in ppm reported using residual solvent as the internal reference in all cases. Signal splitting patterns are described as singlet $(\mathrm{s})$, doublet $(\mathrm{d})$, triplet $(\mathrm{t})$, multiplet $(\mathrm{m})$, or a combination thereof. Coupling constants $(J)$ are quoted to the nearest $0.1 \mathrm{~Hz}$.

\subsubsection{General method to obtain di-tert-butyl protected carboxylate $(A)$ :}

To a solution of diol (1 eq.) in dichloromethane (DCM) ( $4 \mathrm{~mL}$ per mmol), tert-butyl bromoacetate (8 eq.), TBABr (1.1 eq.) and 37\% w/w aqueous $\mathrm{NaOH}$ ( $4 \mathrm{~mL}$ per mmol) were added. The biphasic reaction was vigorously stirred at room temperature (r.t.) overnight. The organic phase was separated from the aqueous layer and then the aqueous phase was extracted with DCM (x3). Organic layers were collected, dried over $\mathrm{MgSO}_{4}$ and evaporated under reduced pressure. The crude was purified by flash chromatography (using a gradient from 10 to $100 \%$ of ethyl acetate in heptane).

\subsubsection{General method B:}

A solution of the starting material in a $50 \% \mathrm{v} / \mathrm{v}$ trifluoroacetic acid (TFA) in DCM ( $6 \mathrm{~mL}$ per mmol) was stirred at r.t. for $2 \mathrm{~h}$. TLC analysis (10\% methanol in DCM) showed complete conversion of the starting material. Then, the reaction mixture was concentrated under reduced pressure and the crude was freeze-dried to obtain the desired product.

\subsubsection{General method C:}

Potassium tert-butoxide ( 1 eq.) was added to polyethylene glycol (8 eq.) in anhydrous THF $(0.2 \mathrm{~mL} / \mathrm{mmol})$ at $0{ }^{\circ} \mathrm{C}$. The resulting mixture was stirred at $60^{\circ} \mathrm{C}$ for $0.5 \mathrm{~h}$, then it was cooled to r.t. A solution of tertbutyl-bromoacetate (1.0 eq.) in anhydrous THF $(0.1 \mathrm{~mL} / \mathrm{mmol})$ was added to the reaction mixture at r.t. The resulting mixture was stirred at r.t. for $24 \mathrm{~h}$. The reaction was quenched with brine and the aqueous phase was extracted with ethyl acetate. The combined organic phase was evaporated to dryness. The crude material was purified by column chromatography (from 0 to $8 \%$ of methanol in DCM) to afford the desired compound.

\subsubsection{General method $D$ :}

Iodine ( 1.3 eq.) was added to triphenylphosiphine (1.3 eq.) and imidazole ( 1.3 eq.) in DCM $(7 \mathrm{~mL} / \mathrm{mmol})$ at $0{ }^{\circ} \mathrm{C}$. The resulting mixture was stirred at r.t. for $5 \mathrm{~min}$, then was cooled to $0{ }^{\circ} \mathrm{C}$. A solution of alcohol (1.0 eq.) in DCM $(3 \mathrm{~mL} / \mathrm{mmol})$ was added to the reaction mixture at $0{ }^{\circ} \mathrm{C}$ and the resulting mixture was stirred at r.t. for $3 \mathrm{~h}$. TLC analysis (50\% ethyl acetate in heptane) showed complete conversion of the starting material. The reaction was quenched with saturated $\mathrm{NaHCO}_{3}$ solution and saturated $\mathrm{Na}_{2} \mathrm{SO}_{3}$ solution and the aqueous phase was extracted with ethyl acetate. The combined organic phase was evaporated to dryness. The crude material was purified by column chromatography (from 20 to $75 \%$ of ethyl acetate in heptane) to afford the desired compound.

\subsubsection{General method E:}

The dicarboxylic acid linker (1 eq.) and NHS (1.1 eq.) were dissolved in dry DCM ( $\sim 10 \mathrm{~mL}$ per mmol). DCC (1.2 eq.) was added and the reaction was left to stir overnight. The DCU was filtered off, the solution was evaporated and the residue dissolved in dry DMF. Compound 3 ( 0.5 eq.) and DIPEA ( 3 eq.) were added. The reaction mixture was left to stir at r.t. for $2 \mathrm{~h}$, quenched with ice, dried under high vacuum and purified by HPLC using a gradient from $10 \%$ to $80 \%$ $\mathrm{v} / \mathrm{v}$ acetonitrile with $0.01 \% \mathrm{v} / \mathrm{v}$ aqueous solution of formic acid over 15 min to yield the desired compound.

\subsubsection{General method F:}

To a solution of carboxylic compound (1 eq.) in dry DMF $(\sim 50 \mathrm{~mL}$ per mmol), COMU (1 eq.), compound 1 (1.1 eq.) and DIPEA ( 3 eq.) were added. The reaction mixture was left to stir for $1 \mathrm{~h}$ and monitored by LC-MS (acidic method). When completed, ice was added to quench the reaction, the volatiles were evaporated under reduced pressure and the residue purified by HPLC with a gradient from $5 \%$ to $90 \% \mathrm{v} / \mathrm{v}$ acetonitrile with $0.01 \% \mathrm{v} / \mathrm{v}$ aqueous solution of formic acid over $15 \mathrm{~min}$ to yield the desired compound.

\subsubsection{General method G:}

To a solution of 20 (1 eq.) and the linker (1.1 eq.) in dry DMF $\left(\sim 14 \mathrm{~mL}\right.$ per mmol), DBU (1.1 eq.) was added at $0{ }^{\circ} \mathrm{C}$ under a nitrogen atmosphere. The reaction mixture was stirred at r.t. for $4 \mathrm{~h}$ and monitored by LC-MS (acidic method). The reaction was quenched with a $5 \%$ $\mathrm{v} / \mathrm{v}$ aqueous solution of citric acid and the solvent was evaporated under high vacuum. The crude was purified by HPLC using a gradient from $5 \%$ to $90 \% \mathrm{v} / \mathrm{v}$ acetonitrile with $0.01 \% \mathrm{v} / \mathrm{v}$ aqueous solution of formic acid over $15 \mathrm{~min}$ to yield the desired compound.

\subsubsection{General method $H$ :}

To a solution of the carboxylic compound (1 eq.) in dry DMF ( $\sim 100 \mathrm{~mL}$ per mmol), COMU (1 eq.), compound 3 (1.1 eq.) and DIPEA ( 3 eq.) were added. The reaction mixture was left to stir for $1 \mathrm{~h}$ and monitored by LC-MS (acidic method). Then, ice was added to quench the reaction, the volatiles were evaporated under reduced pressure and the residue purified by HPLC using a gradient from $5 \%$ to $90 \% \mathrm{v} / \mathrm{v}$ acetonitrile with $0.01 \% \mathrm{v} / \mathrm{v}$ aqueous solution of formic acid over 15 min to yield the desired compound.

\subsubsection{General method I:}

Compound 2 ( 1 eq.), $\mathrm{K}_{2} \mathrm{CO}_{3}$ ( 3 eq.) and the halogenated linker (1.5 eq.) was dissolved in DMF ( $\sim 50 \mathrm{~mL}$ per $\mathrm{mmol}$ ) and heated at $70{ }^{\circ} \mathrm{C}$ overnight. Complete conversion of the starting material was observed by LC-MS (acidic method). The reaction mixture was taken up with water and extracted with DCM (x3). Organic layers were collected, dried over $\mathrm{MgSO}_{4}$, evaporated under reduced pressure and purified by HPLC using a gradient from $5 \%$ to $95 \%$ acetonitrile with $0.01 \% \mathrm{v} / \mathrm{v}$ aqueous solution of formic acid over $10 \mathrm{~min}$ to yield the desired compound.

\subsubsection{Tert-butyl(S)-16-((2S,4R)-4-hydroxy-2-((4-(4-methylthiazol-5-yl)} benzyl)carbamoyl)pyrrolidine-1-carbonyl)-17,17-dimethyl-14-oxo-

3,6,9,12-tetraoxa-15-azaoctadecanoate (6a)

To a solution of compound 5 a $(59.83 \mathrm{mg}, 0.22 \mathrm{mmol}, 1$ eq.), in $1.5 \mathrm{~mL}$ DMF, HATU $(81.74 \mathrm{mg}, 0.22 \mathrm{mmol}, 1$ eq.), HOAT $(29.26 \mathrm{mg}$, $0.22 \mathrm{mmol}, 1$ eq.) were added and the solution was stirred at r.t. for $5 \mathrm{~min}$. Compound 1 ( $100 \mathrm{mg}, 0.215 \mathrm{mmol}, 1$ eq.) was added and the $\mathrm{pH}$ of the reaction mixture was adjusted to $>9$ by addition of DIPEA $(\sim 3$ eq.). The mixture was stirred at r.t. until no presence of the starting materials was detected by LC-MS (acidic method). Water was added and the mixture was extracted with ethyl acetate $(\times 3)$. The combined organic phases were washed with brine $(\times 2)$, dried over $\mathrm{MgSO}_{4}$ and evaporated under reduced pressure to give the corresponding crude which was purified by HPLC using a gradient of $20 \%$ to $95 \% \mathrm{v} / \mathrm{v}$ acetonitrile in $0.01 \%$ aqueous solution of ammonia over $10 \mathrm{~min}$ to yield the final compound (72.8 mg, yield: $51 \%$ ). $\left.{ }^{1} \mathrm{H} \mathrm{NMR} \mathrm{(400} \mathrm{MHz,} \mathrm{CDCl}_{3}\right) \delta$ 8.94 (s, 1H), 7.42-7.36 (m, 1H), 7.32-7.20 (m, 5H), 4.67-4.63 (m, 1H), 4.53-4.42 (m, 3H), 4.31-4.25 (m, 1H), 4.01-3.87 (m, 5H), 3.64-3.55 (m, 18H), 2.47-2.34 (m, 4H), 2.11-2.04 (m, 1H), 1.40 (s, 9H), 0.91 (s, 9H); ${ }^{13} \mathrm{C}$ NMR $\left(126 \mathrm{MHz}, \mathrm{CDCl}_{3}\right) \delta 171.3,171.1,170.5,170.0,151.7$, 139.1, 129.4, 128.3, 82.0, 71.1, 70.6, 70.4, 70.3, 70.2, 68.9, 58.7, 57.3, 56.8, 43.1, 36.3, 35.1, 28.1, 26.4, 15.1. MS: calculated for: $\mathrm{C}_{34} \mathrm{H}_{51} \mathrm{~N}_{4} \mathrm{O}_{9} \mathrm{~S}_{2}[\mathrm{M}+\mathrm{H}]^{+}: m / z=691.3$; observed: $m / z=691.4$. 
4.1.11. (2S,4R)-1-((2S)-2-(tert-butyl)-17-((2-(2,6-dioxopiperidin-3-yl)1,3-dioxoisoindolin-4-yl)amino)-4,14-dioxo-6,9,12-trioxa-3,15diazaheptadecanoyl)-4-hydroxy-N-(4-(4-methylthiazol-5-yl)benzyl) pyrrolidine-2-carboxamide (7a)

Following general method B from compound $6 \mathbf{6 a}(72.3 \mathrm{mg}$, $0.11 \mathrm{mmol}, 1$ eq.), the carboxylic acid derivative was obtained as an oil. The compound was used for the next step without further purification. Yield: $99.3 \mathrm{mg}, 0.11 \mathrm{mmol}$ (quantitative). MS (ESI) $\mathrm{m} / z:[\mathrm{M}+\mathrm{H}]^{+}$ calculated for: $\mathrm{C}_{30} \mathrm{H}_{42} \mathrm{~N}_{4} \mathrm{O}_{9} \mathrm{~S}$ : 634.27; observed: 635.3 .

To a solution of the crude carboxylic acid $(21.16 \mathrm{mg}, 0.028 \mathrm{mmol}, 1$ eq.) in DMF (0.5 mL) was added HATU ( $10.64 \mathrm{mg}, 0.028 \mathrm{mmol}, 1$ eq.) and HOAT ( $3.81 \mathrm{mg}, 0.028 \mathrm{mmol}, 1 \mathrm{eq}$.). The resulting mixture was stirred at r.t. for $5 \mathrm{~min}$. Compound $3(10 \mathrm{mg}, 0.028 \mathrm{mmol}, 1$ eq.) was added and the $\mathrm{pH}$ of the reaction mixture was adjusted to $>9$ by addition of DIPEA ( $\sim 3$ eq.). The mixture was stirred at r.t. until no presence of the starting materials was detected by LC-MS. The solvent was evaporated under reduced pressure to give the corresponding crude which was purified by HPLC using a gradient of $5 \%$ to $95 \% \mathrm{v} / \mathrm{v}$ acetonitrile with $0.01 \%$ aqueous solution of formic acid over $15 \mathrm{~min}$ to yield the final compound as a yellow solid. Yield: $25 \mathrm{mg}, 0.026 \mathrm{mmol}$ (95\%). ${ }^{1} \mathrm{H}$ NMR $\left(500 \mathrm{MHz}, \mathrm{CDCl}_{3}\right) \delta 8.62(\mathrm{~s}, 0.5 \mathrm{H}), 8.61(\mathrm{~s}, 0.5 \mathrm{H}), 7.60-7.54$ (m, 1H), 7.48-7.38 (m, 2H), 7.30-7.25 (m, 4H), $7.01(\mathrm{~d}, J=7.4 \mathrm{~Hz}$, $1 \mathrm{H}), 6.90$ (d, $J=8.4 \mathrm{~Hz}, 1 \mathrm{H}), 6.41-6.34(\mathrm{~m}, 1 \mathrm{H}), 4.83-4.78(\mathrm{~m}, 1 \mathrm{H})$, 4.59-4.50 (m, 2H), 4.48-4.44 (m, 1H), 4.26-4.21 (m, 1H), 3.97-3.81 (m, 5H), 3.63-3.40 (m, 12H), $2.67(\mathrm{t}, J=4.7 \mathrm{~Hz}, 3 \mathrm{H}), 2.44(\mathrm{~d}$, $J=1.8 \mathrm{~Hz}, 3 \mathrm{H}$ ), 2.35-2.29 (m, 1H), 2.12-2.05 (m, 1H), 2.03-1.97 (m, $2 \mathrm{H}), 0.89$ (s, 9H); ${ }^{13} \mathrm{C}$ NMR $\left(126 \mathrm{MHz}, \mathrm{CDCl}_{3}\right) \delta 172.2,171.4,171.3$, $171.3,170.9,170.8,170.3,170.2$, 169.4, 169.2, 169.1, 167.6, 150.4, $150.4,148.4,148.4,146.8,146.8,138.5,138.5,136.2,132.5,132.5$, 131.7, 131.7, 130.7, 130.7, 129.4, 129.3, 128.1, 116.7, 111.8, 111.8, 110.3, 110.2, 71.1, 70.9, 70.8, 70.3, 70.2, 70.2, 70.1, 60.4, 59.0, 59.0, 57.0, 56.9, 56.8, 50.7, 48.9, 48.9, 43.1, 41.7, 38.8, 38.6, 36.6, 35.6, 35.5, 31.5, 26.5, 26.3, 22.7, 22.7, 16.0, 14.2. HRMS: calculated for: $\mathrm{C}_{45} \mathrm{H}_{57} \mathrm{~N}_{8} \mathrm{O}_{12} \mathrm{~S}[\mathrm{M}+\mathrm{H}]^{+}: m / z=933.3811$; observed: $m / z=933.3826$.

\subsubsection{2. $N_{1}$-(2-((2-(2,6-dioxopiperidin-3-yl)-1,3-dioxoisoindolin-4-yl)} amino)ethyl)-N $N_{17-(}(S)-1-((2 S, 4 R)-4-h y d r o x y-2-((4-(4-m e t h y l t h i a z o l-5-y l)$ benzyl)carbamoyl)pyrrolidin-1-yl)-3,3-dimethyl-1-oxobutan-2-yl)3,6,9,12,15-pentaoxaheptadecanediamide (7b)

To a solution of the Boc-deprotected carboxylic acid derivative of compound $6 \mathbf{b}$ (obtained as described in ref. $\left.{ }^{11}\right)(23.88 \mathrm{mg}, 0.028 \mathrm{mmol}$, 1 eq.) in dry DMF ( $0.5 \mathrm{~mL})$, HATU ( $10.64 \mathrm{mg}, 0.028 \mathrm{mmol}, 1 \mathrm{eq}$.$) and$ HOAT ( $3.81 \mathrm{mg}, 0.028 \mathrm{mmol}$, 1 eq.) were added. The solution was stirred for $5 \mathrm{~min}$, compound 3 ( $10 \mathrm{mg}, 0.028 \mathrm{mmol}, 1 \mathrm{eq}$.) was added and the $\mathrm{pH}$ of the reaction was adjusted to $>9$ with DIPEA. The mixture was stirred at r.t. until no presence of the starting materials was detected by LC-MS. Water was added and the mixture was extracted with ethyl acetate $(\times 3)$. The combined organic phases were washed with brine $(\times 2)$, dried over $\mathrm{MgSO}_{4}$ and evaporated under reduced pressure to give the corresponding crude, which was purified by HPLC using a gradient of $20 \%$ to $95 \% \mathrm{v} / \mathrm{v}$ acetonitrile with $0.01 \%$ aqueous solution of ammonia over $10 \mathrm{~min}$ to yield the final compound as a white solid (24 mg, yield: $84 \%) .{ }^{1} \mathrm{H} \mathrm{NMR}\left(500 \mathrm{MHz}, \mathrm{CDCl}_{3}\right) \delta 8.70(\mathrm{~s}, 0.5 \mathrm{H})$, 8.69 (s, 0.5H), 7.64-7.58 (m, 1H), 7.55-7.49 (m, 1H), 7.43-7.40 (m, $1 \mathrm{H}), 7.32-7.27(\mathrm{~m}, 5 \mathrm{H}), 7.02-6.95(\mathrm{~m}, 2 \mathrm{H}), 4.84-4.77(\mathrm{~m}, 1 \mathrm{H})$, 4.66-4.59 (m, 1H), 4.56-4.48 (m, 2H), 4.28-4.23 (m, 1H), 3.95-3.82 (m, 4H), 3.63-3.36 (m, 22H), 2.46-2.44 (m, 4H), 2.41-2.34 (m, 1H), 2.14-2.08 (m, 1H), 0.90 (s, 9H); ${ }^{13} \mathrm{C}$ NMR $\left(126 \mathrm{MHz}, \mathrm{CDCl}_{3}\right) \delta: 171.3$, $171.2,171.1,170.5,170.3,169.4,168.9,167.6,150.7,150.6,147.9$, $146.8,146.8,138.7,138.6,136.2,132.5,132.0,130.5,130.4,129.4$, 129.3, 128.2, 117.0, 111.7, 110.1, 70.9, 70.6, 70.5, 70.4, 70.3, 70.2, 70.1, 70.0, 59.0, 58.8, 57.0, 56.9, 48.9, 43.2, 41.9, 38.4, 38.3, 36.5, 35.4, 35.3, 31.5, 26.4, 22.7, 15.8. HRMS calculated for: $\mathrm{C}_{49} \mathrm{H}_{65} \mathrm{~N}_{8} \mathrm{O}_{14} \mathrm{~S}$ $[\mathrm{M}+\mathrm{H}]^{+}: m / z=1021.4335$; observed: $m / z=1021.4546[\mathrm{M}+\mathrm{H}]^{+}$.

\subsubsection{3,9,12,18-tetraoxaicosanedioic acid (12a)}

Starting from compound $11 \mathrm{a}(83 \mathrm{mg}, 0.17 \mathrm{mmol})$ and following the general method B compound 12a was obtained in quantitative yield (64 mg). ${ }^{1} \mathrm{H}$ NMR (500 MHz, $\mathrm{CDCl}_{3}$ ) $\delta: 8.06$ (s, 2H), 4.09 (s, 4H), 3.59 (s, 4H), 3.56 (t, $J=6.5 \mathrm{~Hz}, 4 \mathrm{H}), 3.49$ (t, $J=6.5 \mathrm{~Hz}, 4 \mathrm{H}), 1.66-1.58$ (m, $8 \mathrm{H}), 1.47-1.41(\mathrm{~m}, 4 \mathrm{H}) ;{ }^{13} \mathrm{C}$ NMR $\left(101 \mathrm{MHz}, \mathrm{CDCl}_{3}\right) \delta: 174.4,72.0$, 71.4, 70.1, 67.9, 29.2, 29.1, 22.6 .

4.1.14. 1-((2-(2,6-dioxopiperidin-3-yl)-1,3-dioxoisoindolin-4-yl)amino)4-oxo-6,12,15,21-tetraoxa-3-azatricosan-23-oic acid (13a)

Starting from compound 12a (36 mg, $0.098 \mathrm{mmol}, 1 \mathrm{eq})$ and following the general method $\mathbf{E}$, the title compound was obtained (14 mg, yield: $44 \%$ ). ${ }^{1} \mathrm{H}$ NMR $\left(500 \mathrm{MHz}, \mathrm{CDCl}_{3}\right.$ ) $\delta: 7.48$ (dd, $J=7.2$, $8.6 \mathrm{~Hz}, 1 \mathrm{H}), 7.09(\mathrm{~d}, J=7.1 \mathrm{~Hz}, 1 \mathrm{H}), 6.98(\mathrm{~d}, J=8.9 \mathrm{~Hz}, 1 \mathrm{H})$, 4.93-4.89 (m, 1H), 4.04 (s, 2H), 3.93 (s, 2H), 3.55-3.41 (m, 16H), 2.88-2.66 (m, 3H), 2.13-2.06 (m, 1H), 1.64-1.52 (m, 8H), 1.46-1.32 (m, 4H); ${ }^{13} \mathrm{C}$ NMR $\left(126 \mathrm{MHz}, \mathrm{CDCl}_{3}\right) \delta: 172.4,171.7,171.4,169.5$, $168.8,167.7,146.9,136.4,132.7,116.9,112.1,110.7,71.9,71.3$, 71.2, 70.3, 70.2, 68.1, 49.1, 42.3, 38.6, 31.6, 29.4, 29.3, 22.9, 22.7. MS: calculated for $\mathrm{C}_{31} \mathrm{H}_{44} \mathrm{~N}_{4} \mathrm{O}_{11}[\mathrm{M}+\mathrm{H}]^{+}: \mathrm{m} / z=649.3$; observed: $m$ / $z=649.0$

4.1.15. $N^{1}$-(2-((2-(2,6-dioxopiperidin-3-yl)-1,3-dioxoisoindolin-4-yl) amino)ethyl)- $N^{20}-((S)-1-((2 S, 4 R)-4-h y d r o x y-2-((4-(4-m e t h y l t h i a z o l-5-y l)$ benzyl)carbamoyl)pyrrolidin-1-yl)-3,3-dimethyl-1-oxobutan-2-yl)-

3,9,12,18-tetraoxaicosanediamide (14a)

Starting from compound 13a (14 mg, $0.02 \mathrm{mmol}, 1$ eq.) and following the general method $\mathbf{F}$, the title compound was obtained (12 mg, yield: 52\%). ${ }^{1} \mathrm{H}$ NMR (400 MHz, MeOD) $\delta: 9.00(\mathrm{~s}, 1 \mathrm{H})$, 7.56-7.52 (m, 1H), 7.48-7.41 (m, $J=8.5,20.5 \mathrm{~Hz}, 4 \mathrm{H}), 7.14$ (d, $J=8.5 \mathrm{~Hz}, 1 \mathrm{H}), 7.05(\mathrm{~d}, J=7.5 \mathrm{~Hz}, 1 \mathrm{H}), 5.05(\mathrm{dd}, J=5.2,12.7 \mathrm{~Hz}$, $1 \mathrm{H}), \quad 4.70(\mathrm{~d}, J=10.3 \mathrm{~Hz}, 1 \mathrm{H}), 4.60-4.50(\mathrm{~m}, 3 \mathrm{H}), 4.36(\mathrm{~d}$, $J=16.0 \mathrm{~Hz}, 1 \mathrm{H}), 3.96(\mathrm{~d}, J=6.9 \mathrm{~Hz}, 2 \mathrm{H}), 3.91-3.78(\mathrm{~m}, 4 \mathrm{H}), 3.47(\mathrm{~m}$, $J=7.9,28.1 \mathrm{~Hz}, 16 \mathrm{H}), 2.90-2.64(\mathrm{~m}, 3 \mathrm{H}), 2.48(\mathrm{~s}, 3 \mathrm{H}), 2.26-2.21(\mathrm{~m}$, 1H), 2.12-2.05 (m, 2H), 1.68-1.33 (m, 12H), 1.03 (s, 9H); ${ }^{13} \mathrm{C}$ NMR (101 MHz, MeOD) $\delta: 174.5,174.2,173.4,172.0,171.9,171.6,171.4$, $170.5,169.1,153.1,148.2,148.0,140.4,137.1,133.8,133.7,131.0$, 130.3, 129.4, 128.9, 118.0, 112.0, 111.3, 72.7, 72.6, 72.0, 71.0, 70.8, 70.6, 66.8, 60.7, 58.0, 57.9, 43.6, 42.6, 39.3, 38.8, 37.1, 32.1, 30.3, 30.1, 26.8, 23.7, 23.6, 15.5, 15.3. HRMS: calculated for $\mathrm{C}_{53} \mathrm{H}_{73} \mathrm{~N}_{8} \mathrm{O}_{13} \mathrm{~S}$ $[\mathrm{M}+\mathrm{H}]^{+}: m / z=1061.5012$; observed: $m / z=1061.5065$.

\subsubsection{2,2'-(hexane-1,6-diylbis(ox))diacetic acid (12b)}

Starting from compound 11b (185 mg, $0.53 \mathrm{mmol})$ and following the general method B compound $\mathbf{1 2 b}$ was obtained in quantitative yield (125 mg). ${ }^{1} \mathrm{H}$ NMR (400 MHz, DMSO) $\delta: 12.49$ (s, 2H), 3.97 (s, $4 \mathrm{H}), 3.43(\mathrm{t}, J=6.6 \mathrm{~Hz}, 4 \mathrm{H}), 1.55-1.47(\mathrm{~m}, 4 \mathrm{H}), 1.34-1.28(\mathrm{~m}, 4 \mathrm{H})$; ${ }^{13} \mathrm{C}-\mathrm{NMR}$ (101 MHz, DMSO) $\delta 171.6,70.4,67.4,29.0,25.3$.

4.1.17. 2-((6-(2-)(2-((2-(2,6-dioxopiperidin-3-yl)-1,3-dioxoisoindolin-4yl)amino)ethyl)amino)-2-oxoethoxy)hexyl)oxy)acetic acid (13b)

To a solution of compound $\mathbf{1 2 b}(15.0 \mathrm{mg}, 0.064 \mathrm{mmol}, 1 \mathrm{eq}$.$) and$ following the general method $\mathbf{E}$, the title compound was obtained (7 mg, yield: $41 \%$ ). ${ }^{1} \mathrm{H}$ NMR (400 MHz, MeOD) $\delta: 7.56$ (dd, $J=7.1$, $8.6 \mathrm{~Hz}, 1 \mathrm{H}$ ), 7.15 (d, $J=8.6 \mathrm{~Hz}, 1 \mathrm{H}$ ), 7.07 (d, $J=7.1 \mathrm{~Hz}, 1 \mathrm{H}), 5.05$ (dd, $J=5.5,12.5 \mathrm{~Hz}, 1 \mathrm{H}), 4.02(\mathrm{~s}, 2 \mathrm{H}), 3.90(\mathrm{~s}, 2 \mathrm{H}), 3.52-3.45(\mathrm{~m}$, 8H), 2.91-2.67 (m, 3H), 2.15-2.08 (m, 1H), 1.63-1.55 (m, 4H), $1.38-1.34$ (m, 4H); ${ }^{13} \mathrm{C}$ NMR (126 MHz, MeOD) $\delta: 174.6,174.1,173.5$, $171.5,170.6,169.3,148.2$, 137.2, 134.0, 118.1, 112.1, 111.5, 72.8, 72.6, 70.9, 68.7, 42.7, 39.4, 32.2, 30.4, 26.8, 23.8. MS: calculated for $\mathrm{C}_{25} \mathrm{H}_{33} \mathrm{~N}_{4} \mathrm{O}_{9}[\mathrm{M}+\mathrm{H}]^{+}: m / z=532.2$; observed: $m / z=533.3$. 
4.1.18. (2S,4R)-1-((2S)-2-(tert-butyl)-18-((2-(2,6-dioxopiperidin-3-yl)-

1,3-dioxoisoindolin-4-yl)amino)-4,15-dioxo-6,13-dioxa-3,16-

diazaoctadecanoyl)-4-hydroxy-N-(4-(4-methylthiazol-5-yl)benzyl)

pyrrolidine-2-carboxamide (14b)

Starting from compound 13b $(7 \mathrm{mg}, 0.013 \mathrm{mmol}, 1 \mathrm{eq})$ and following the general method $\mathbf{F}$, the title compound was obtained (7.7 mg, yield: $62 \%$ ). ${ }^{1} \mathrm{H}$ NMR $(400 \mathrm{MHz}, \mathrm{MeOD}) \delta: 8.99$ (s, $\left.1 \mathrm{H}\right)$, 7.56-7.49 (m, 1H), 7.44 (dd, $J=7.9,21.3 \mathrm{~Hz}, 4 \mathrm{H}), 7.11(\mathrm{~d}, J=8.9 \mathrm{~Hz}$, $1 \mathrm{H}), 7.05(\mathrm{~d}, J=7.0 \mathrm{~Hz}, 1 \mathrm{H}), 5.04$ (dd, $J=5.6,12.6 \mathrm{~Hz}, 1 \mathrm{H}$ ), $4.71-4.68(\mathrm{~m}, 1 \mathrm{H}), 4.61-4.33(\mathrm{~m}, 4 \mathrm{H}), 3.95(\mathrm{~d}, J=6.3 \mathrm{~Hz}, 2 \mathrm{H})$, 3.91-3.78 (m, 4H), 3.54-3.42 (m, 8H), 2.85-2.63 (m, 3H), 2.48 (s, 3H), 2.26-2.21 (m, 1H), 2.10-2.07 (m, 2H), 1.63-1.56 (m, 4H), 1.40-1.31 (m, 4H), 1.03 (s, 9H). ${ }^{13} \mathrm{C}-\mathrm{NMR}(101 \mathrm{MHz}, \mathrm{MeOD}) \delta: 174.4,174.1$, $173.3,171.8,171.5,171.3,170.4,169.0,153.0,148.0,140.3,137.0$, 133.8, 130.9, 130.2, 128.9, 117.9, 112.0, 111.2, 72.7, 72.5, 70.9, 70.7, 70.5, 60.6, 57.9, 57.8, 43.5, 42.5, 39.2, 38.7, 37.0, 32.0, 30.3, 30.2, 26.7, 26.6, 23.6, 15.2. HRMS: calculated for $\mathrm{C}_{47} \mathrm{H}_{61} \mathrm{~N}_{8} \mathrm{O}_{11} \mathrm{~S}[\mathrm{M}+\mathrm{H}]^{+}$: $m / z=945.4175$; observed: $m / z=945.4270$.

\subsubsection{3,6,9,12,15,18-hexaoxaicosanedioic acid (12c)}

Starting from compound $11 \mathrm{c}(300 \mathrm{mg}, 0.64 \mathrm{mmol})$ and following the general method B compound 12c was obtained in quantitative yield $(226 \mathrm{mg})$. Analytical data matched those previously reported. ${ }^{61}$

4.1.20. 1-((2-(2,6-dioxopiperidin-3-yl)-1,3-dioxoisoindolin-4-yl)amino)4-oxo-6,9,12,15,18,21-hexaoxa-3-azatricosan-23-oic acid (13c)

Starting from compound 12c ( $23 \mathrm{mg}, 0.065 \mathrm{mmol}, 1 \mathrm{eq}$.) and following the general method $\mathbf{E}$, the title compound was obtained $(5.9 \mathrm{mg}, 28 \%) .{ }^{1} \mathrm{H}$ NMR $\left(400 \mathrm{MHz}, \mathrm{CDCl}_{3}\right) \delta: 7.49(\mathrm{t}, J=7.8 \mathrm{~Hz}, 1 \mathrm{H})$, $7.08(\mathrm{~d}, J=6.8 \mathrm{~Hz}, 1 \mathrm{H}), 7.03(\mathrm{~d}, J=8.4 \mathrm{~Hz}, 1 \mathrm{H}), 4.93-4.86(\mathrm{~m}, 1 \mathrm{H})$, 4.10 (s, 2H), 3.97 (s, 2H), 3.72-3.45 (m, 24H), 2.89-2.65 (m, 3H), 2.13-2.07 (m, 1H); ${ }^{13} \mathrm{C}$ NMR $\left(126 \mathrm{MHz}, \mathrm{CDCl}_{3}\right) \delta: 172.5,171.4,171.3$, $169.4,168.7,167.8,147.0,136.4,132.7,117.0,111.9,110.5,71.0$, 70.5, 70.4, 70.3, 70.2, 69.4, 49.1, 42.0, 38.5, 31.6, 22.9. MS: calculated for $\mathrm{C}_{29} \mathrm{H}_{41} \mathrm{~N}_{4} \mathrm{O}_{13}[\mathrm{M}+\mathrm{H}]^{+}: m / z=653.2$ observed: $m / z=653.3$.

4.1.21. $N^{1}$-(2-((2-(2,6-dioxopiperidin-3-yl)-1,3-dioxoisoindolin-4-yl) amino)ethyl)- $N^{20}-((S)-1-((2 S, 4 R)-4-h y d r o x y-2-((4-(4-m e t h y l t h i a z o l-5-y l)$ benzyl)carbamoyl)pyrrolidin-1-yl)-3,3-dimethyl-1-oxobutan-2-yl)-

3,6,9,12,15,18-hexaoxaicosanediamide (14c)

Starting from compound 13c $(5.9 \mathrm{mg}, 0.0090 \mathrm{mmol}, 1 \mathrm{eq}$.$) and$ following the general method $F$, the title compound was obtained (4 mg, yield: 42\%). ${ }^{1} \mathrm{H}$ NMR (400 MHz, MeOD) $\delta: 8.86$ (s, 1H), 7.55 (dd, $J=7.1 ， 8.5 \mathrm{~Hz}, 1 \mathrm{H}), 7.44(\mathrm{dd}, J=8.2,18.7 \mathrm{~Hz}, 4 \mathrm{H}), 7.14$ (d, $J=8.5 \mathrm{~Hz}, 1 \mathrm{H}), 7.05(\mathrm{~d}, J=7.1 \mathrm{~Hz}, 1 \mathrm{H}), 5.04(\mathrm{dd}, J=5.6,12.8 \mathrm{~Hz}$, $1 \mathrm{H}), 4.70(\mathrm{~s}, 1 \mathrm{H}), 4.61-4.48(\mathrm{~m}, 3 \mathrm{H}), 4.35(\mathrm{~d}, J=14.2 \mathrm{~Hz}, 1 \mathrm{H}), 4.03$ (d, $J=4.4 \mathrm{~Hz}, 2 \mathrm{H}), 3.95$ (s, 2H), 3.90-3.77 (m, 2H), 3.71-3.58 (m, 20H), 3.52-3.49 (m, 4H), 2.89-2.65 (m, 3H), 2.47(s, 3H), 2.26-2.18 (m, 1H), 2.14-2.05 (m, 2H), 1.04 (s, 9H). ${ }^{13} \mathrm{C}-\mathrm{NMR}$ (101 MHz, MeOD) $\delta$ $174.7,174.4,173.6,172.1,171.7,171.5,170.6,169.3,152.8,149.1$, $148.2,140.3,137.3,134.0,133.4,131.6,130.4,129.0,118.2,112.1$, 111.5, 72.3, 72.0, 71.7, 71.6, 71.5, 71.3, 71.1, 60.8, 58.2, 58.1, 43.8, 42.5, 39.4, 38.9, 37.1, 32.2, 27.0, 23.8, 15.9. HRMS: calculated for $\mathrm{C}_{51} \mathrm{H}_{72} \mathrm{~N}_{9} \mathrm{O}_{15} \mathrm{~S} \quad\left[\mathrm{M}+\mathrm{NH}_{4}\right]^{+}: \quad m / z=1082.4863 ; \quad$ observed: $\mathrm{m} /$ $z=1082.4790$

4.1.22. 3,6,9,12,15,18,21,24,27-nonaoxanonacosanedioic acid (12d)

Starting from compound 11d $(100 \mathrm{mg}, 0.17 \mathrm{mmol})$ and following the general method B compound 12d was obtained in quantitative yield $(80 \mathrm{mg}) .{ }^{1} \mathrm{H}$ NMR $\left(400 \mathrm{MHz}, \mathrm{D}_{2} \mathrm{O}\right) \delta: 4.32(4 \mathrm{H}, \mathrm{s}), 3.87-3.78(32 \mathrm{H}$, m)

4.1.23. 1-((2-(2,6-dioxopiperidin-3-yl)-1,3-dioxoisoindolin-4-yl)amino)4-oxo-6,9,12,15,18,21,24,27,30-nonaoxa-3-azadotriacontan-32-oic acid (13d)

Starting from compound 12d (4.6 $\mathrm{mg}, 0.010 \mathrm{mmol}$, 1 eq.) and following the general method $\mathbf{E}$, the title compound was obtained (8.5 mg, yield: $22 \%$ ). ${ }^{1} \mathrm{H}$ NMR ( $500 \mathrm{MHz}, \mathrm{CDCl}_{3}$ ) $\delta: 7.49$ (dd, $J=7.2$, $8.5 \mathrm{~Hz}, 1 \mathrm{H}), 7.08(\mathrm{~d}, J=7.1 \mathrm{~Hz}, 1 \mathrm{H}), 7.02(\mathrm{~d}, J=8.6 \mathrm{~Hz}, 1 \mathrm{H}), 4.89$ (dd, $J=5.5,12.3 \mathrm{~Hz}, 1 \mathrm{H}), 4.12(\mathrm{~s}, 2 \mathrm{H}), 3.98(\mathrm{~s}, 2 \mathrm{H}), 3.72-3.48(\mathrm{~m}$, $36 \mathrm{H}), 2.89-2.69(\mathrm{~m}, 3 \mathrm{H}), 2.12-2.08(\mathrm{~m}, 1 \mathrm{H}) ;{ }^{13} \mathrm{C} \mathrm{NMR}(126 \mathrm{MHz}$, $\left.\mathrm{CDCl}_{3}\right) \delta: 172.1,171.4,169.4,168.6,167.7,147.0,136.4,132.7,117.0$, 111.9, 110.5, 71.1, 70.8, 70.7, 70.6, 70.5, 70.4, 70.2, 69.3, 49.1, 42.1, 38.6, 31.6, 22.9. MS: calculated for $\mathrm{C}_{35} \mathrm{H}_{53} \mathrm{~N}_{4} \mathrm{O}_{16}[\mathrm{M}+\mathrm{H}]^{+}: \mathrm{m} /$ $z=785.3$; observed: $m / z=785.8$.

4.1.24. $\quad N^{1}$-(2-((2-(2,6-dioxopiperidin-3-yl)-1,3-dioxoisoindolin-4-yl) amino)ethyl)- $N^{29}-((S)-1-((2 S, 4 R)-4-h y d r o x y-2-((4-(4-m e t h y l t h i a z o l-5-y l)$ benzyl)carbamoyl)pyrrolidin-1-yl)-3,3-dimethyl-1-oxobutan-2-yl)-

3,6,9,12,15,18,21,24,27-nonaoxanonacosanediamide (14d)

Starting from compound 13d $(8.5 \mathrm{mg}, 0.0108 \mathrm{mmol}, 1 \mathrm{eq}$.$) and$ following the general method $\mathbf{F}$, the title compound was obtained (7.0 mg, yield: 54\%). ${ }^{1} \mathrm{H}$ NMR (500 MHz, MeOD) $\delta: 8.87$ (s, 1H), 7.55 (dd, $J=7.2,8.6 \mathrm{~Hz}, 1 \mathrm{H}$ ), 7.44 (dd, $J=8.6,22.4 \mathrm{~Hz}, 4 \mathrm{H}$ ), 7.15 (d, $J=8.4 \mathrm{~Hz}, 1 \mathrm{H}), 7.06(\mathrm{~d}, J=7.0 \mathrm{~Hz}, 1 \mathrm{H}), 5.04(\mathrm{dd}, J=5.2,12.4 \mathrm{~Hz}$, $1 \mathrm{H}), 4.70$ (d, $J=9.4 \mathrm{~Hz}, 1 \mathrm{H}), 4.60-4.50(\mathrm{~m}, 3 \mathrm{H}), 4.36$ (dd, $J=4.9$, $15.8 \mathrm{~Hz}, 1 \mathrm{H}), 4.04$ (d, $J=6.1 \mathrm{~Hz}, 2 \mathrm{H}), 3.96(\mathrm{~s}, 2 \mathrm{H}), 3.89-3.79(\mathrm{~m}, 2 \mathrm{H})$, 3.71-3.51 (m, 36H), 2.88-2.66 (m, 3H), 2.47 (s, 3H), 2.24-2.20 (m, 1H), 2.12-2.07 (m, 2H), 1.04 (s, 9H); ${ }^{13} \mathrm{C}-\mathrm{NMR}$ (126 MHz, MeOD) $\delta$ : 174.6, 174.3, 173.5, 172.1, 171.7, 171.4, 170.6, 169.2, 152.8, 149.1, 148.2, 140.3, 137.3, 134.0, 133.4, 131.5, 130.5, 130.4, 129.5, 129.0, $118.2,112.1,111.5,72.3,72.0,71.6,71.5,71.4,71.3,71.1,71.0,60.8$, 58.1, 43.7, 42.5, 39.4, 38.9, 37.1, 32.2, 27.0, 23.8, 15.8. HRMS: calculated for $\mathrm{C}_{57} \mathrm{H}_{89} \mathrm{~N}_{9} \mathrm{O}_{18} \mathrm{~S}\left[\mathrm{M}+\mathrm{NH}_{4}\right]^{+}: m / z=1214.5650$; observed: $m / z=1214$. 5675 .

4.1.25. 1-((2-(2,6-dioxopiperidin-3-yl)-1,3-dioxoisoindolin-4-yl)amino)4-oxo-6,9,12,15-tetraoxa-3-azaheptadecan-17-oic acid (13e)

Starting from compound 12e $(26.6 \mathrm{mg}, 0.10 \mathrm{mmol}, 1 \mathrm{eq}$.$) and fol-$ lowing the general method $\mathbf{E}$, the title compound was obtained (12.5 mg, 44\%). ${ }^{1} \mathrm{H}$ NMR (400 MHz, $\mathrm{CDCl}_{3}$ ) $\delta: 7.47$ (dd, $J=7.2,8.5 \mathrm{~Hz}$, $1 \mathrm{H}), 7.06$ (d, $J=7.2 \mathrm{~Hz}, 1 \mathrm{H}), 7.01$ (d, $J=8.5 \mathrm{~Hz}, 1 \mathrm{H}$ ), 4.90 (dd, $J=5.6,11.7 \mathrm{~Hz}, 1 \mathrm{H}), 4.08$ (s, 2H), 3.99 (s, 2H), 3.72-3.47 (m, 16H), 2.87-2.70 (m, 3H), 2.13-2.05 (m, 1H); ${ }^{13} \mathrm{C}$ NMR (126 MHz, $\left.\mathrm{CDCl}_{3}\right) \delta$ : 172.6 , 171.7, 171.4, 169.5, 169.0, 167.7, 147.0, 136.4, 132.6, 117.1, $111.9,110.4,71.1,71.0,70.5,70.3,69.0,49.1,42.1,38.5,31.6,22.9$. MS analysis: calculated for $\mathrm{C}_{25} \mathrm{H}_{33} \mathrm{~N}_{4} \mathrm{O}_{11}[\mathrm{M}+\mathrm{H}]^{+}: 565.2$ observed: 565.3.

4.1.26. $\quad N^{1}$-(2-((2-(2,6-dioxopiperidin-3-yl)-1,3-dioxoisoindolin-4-yl) amino)ethyl)- $N^{14}-((S)-1-((2 S, 4 R)-4-h y d r o x y-2-((4-(4-m e t h y l t h i a z o l-5-y l)$ benzyl)carbamoyl)pyrrolidin-1-yl)-3,3-dimethyl-1-oxobutan-2-yl)-

3,6,9,12-tetraoxatetradecanediamide (14e)

Starting from compound $13 \mathrm{e}(12.5 \mathrm{mg}, 0.022 \mathrm{mmol}, 1 \mathrm{eq}$.$) and$ following the general method $\mathbf{F}$, the title compound was obtained (9.5 mg, yield: 44\%). ${ }^{1} \mathrm{H}$ NMR (400 MHz, MeOD) $\delta: 8.87$ (s, $1 \mathrm{H}$ ), 7.54 (dd, $J=7.1,8.4 \mathrm{~Hz}, 1 \mathrm{H}), 7.42(\mathrm{dd}, J=8.3,20.1 \mathrm{~Hz}, 4 \mathrm{H}), 7.12(\mathrm{~d}$, $J=8.4 \mathrm{~Hz}, 1 \mathrm{H}), 7.04(\mathrm{~d}, J=7.1 \mathrm{~Hz}, 1 \mathrm{H}), 5.03$ (dd, $J=5.5,12.6 \mathrm{~Hz}$, $1 \mathrm{H}), 4.70$ (d, $J=7.1 \mathrm{~Hz}, 1 \mathrm{H}), 4.61-4.48(\mathrm{~m}, 3 \mathrm{H}), 4.35$ (d, $J=15.3 \mathrm{~Hz}$, $1 \mathrm{H}), 4.03(\mathrm{~d}, J=3.2 \mathrm{~Hz}, 2 \mathrm{H}), 3.94(\mathrm{~s}, 2 \mathrm{H}), 3.88-3.78(\mathrm{~m}, 2 \mathrm{H})$, 3.70-3.49 (m, 16H), 2.89-2.66 (m, 3H), 2.46 (s, 3H), 2.25-2.20 (m, $1 \mathrm{H}), 2.13-2.06(\mathrm{~m}, 2 \mathrm{H}), 1.03$ (s, 9H). ${ }^{13} \mathrm{C}$ NMR (101 MHz, MeOD) $\delta$ : 174.7, 174.4, 173.6, 172.0, 171.7, 171.5, 170.6, 169.3, 152.8, 149.0, $148.2,140.3,137.3,134.0,133.4,131.5,130.4,129.0,112.2,111.5$, 72.2, 72.0, 71.5, 71.4, 71.3, 71.1, 60.8, 58.1, 43.8, 42.5, 39.5, 38.9, 37.1, 32.2, 27.0, 23.8, 15.8. HRMS: calculated for $\mathrm{C}_{47} \mathrm{H}_{61} \mathrm{~N}_{8} \mathrm{O}_{13} \mathrm{~S}$ $[\mathrm{M}+\mathrm{H}]^{+}: m / z=977.4073$; observed: $m / z=977.4079$.

4.1.27. Tert-butyl-2-(2-(2-(2-hydroxyethoxy)ethoxy)ethoxy)acetate (15a)

Starting from triethylene glycol $(6.9 \mathrm{~g}, 41 \mathrm{mmol})$ and following the general method $\mathrm{C}$, the title compound was obtained $(540 \mathrm{mg}$, yield: 40\%). ${ }^{1} \mathrm{H}$ NMR (500 MHz, MeOD) $\delta: 4.02$ (s, 2H), 3.69-3.61 (m, 10H), 
3.55 (t, $J=4.9 \mathrm{~Hz}, 2 \mathrm{H}), 1.48(\mathrm{~s}, 9 \mathrm{H})$. Analytical data matched those previously reported. ${ }^{31}$

\subsubsection{Tert-butyl-2-(2-(2-(2-iodoethoxy)ethoxy)ethoxy)acetate (16a)}

Starting from compound 15a (350 $\mathrm{mg}, 1.33 \mathrm{mmol}$ ) and following the general method $\mathbf{D}$, the title compound was obtained. Yield: $414 \mathrm{mg}$ (79\%). ${ }^{1} \mathrm{H}$ NMR (400 MHz, $\left.\mathrm{CDCl}_{3}\right) \delta: 4.06(\mathrm{~s}, 2 \mathrm{H}), 3.81-3.70(\mathrm{~m}, 10 \mathrm{H})$, $3.28(\mathrm{t}, J=6.9 \mathrm{~Hz}, 2 \mathrm{H}), 1.50(\mathrm{~s}, 9 \mathrm{H}) .{ }^{13} \mathrm{C} \mathrm{NMR}\left(101 \mathrm{MHz}, \mathrm{CDCl}_{3}\right) \delta$ : 169.7, 81.6, 72.0, 70.7, 70.6, 70.2, 69.1, 69.0, 28.1.

\subsubsection{Tert-butyl-2-(2- $(2-(2-(2-)((2 S, 4 R)-1-((S)-2-(1-$}

fluorocyclopropane-1-carboxamido)-3,3-dimethylbutanoyl)-4hydroxypyrrolidine-2-carboxamido)methyl)-5-(4-methylthiazol-5-yl) phenoxy)ethoxy)ethoxy)ethoxy)acetate (17a)

Starting from compound 2 ( $40 \mathrm{mg}, 0.075 \mathrm{mmol}, 1 \mathrm{eq}$ ), 16a (42 mg, $0.11 \mathrm{mmol}, 1.5$ eq.) and $\mathrm{K}_{2} \mathrm{CO}_{3}$ ( $31 \mathrm{mg}, 0.22,3$ eq.), and following the general method $\mathbf{I}$, the titled compound was obtained $(13 \mathrm{mg}$, yield: $22 \%$ ). ${ }^{1} \mathrm{H}$ NMR $\left(500 \mathrm{MHz}, \mathrm{CDCl}_{3}\right.$ ) $\delta: 8.66$ (s, $1 \mathrm{H}$ ), 7.00 (dd, $J=3.4$, $8.9 \mathrm{~Hz}, 1 \mathrm{H}), 6.95$ (dd, $J=1.6,7.6 \mathrm{~Hz}, 1 \mathrm{H}), 6.88$ (d, $J=1.6 \mathrm{~Hz}, 1 \mathrm{H})$, $4.65(\mathrm{t}, J=8.0 \mathrm{~Hz}, 1 \mathrm{H}), 4.53-4.44(\mathrm{~m}, 4 \mathrm{H}), 4.24-4.14(\mathrm{~m}, 2 \mathrm{H})$, 4.00-3.59 (m, 14H), 2.50 (s, 3H), 2.42-2.36 (m, 1H), 2.13-2.08 (m, $1 \mathrm{H}), 1.44$ (s, 9H), 1.32-1.22 (m, 4H), 0.94 (s, 9H); ${ }^{13} \mathrm{C}$ NMR $(126 \mathrm{MHz}$, $\mathrm{CDCl}_{3}$ ) $\delta: 170.8,170.7,170.1\left(\mathrm{~d},{ }^{2} J=20.4 \mathrm{~Hz}\right), 169.8,157.0,150.4$, 148.7, 132.5, 131.9, 130.0, 127.1, 122.2, 113.0, 81.8, 79.5, 70.9, 70.7, 70.4, 69.8, 69.2, 68.1, 58.8, 57.6, 56.7, 39.3, 36.6, 35.7, 28.3, 26.5, $16.3,13.8\left(\mathrm{~d},{ }^{2} J=5.2 \mathrm{~Hz}\right), 13.7\left(\mathrm{~d},{ }^{2} J=5.2 \mathrm{~Hz}\right)$. MS: calculated for $\mathrm{C}_{38} \mathrm{H}_{56} \mathrm{FN}_{4} \mathrm{O}_{10} \mathrm{~S}[\mathrm{M}+\mathrm{H}]^{+}: m / z=779.4$ observed: $m / z=779.7$.

\subsubsection{0. (2S,4R)-N-(2-((1-((2-(2,6-dioxopiperidin-3-yl)-1,3-}

dioxoisoindolin-4-yl)amino)-4-oxo-6,9,12-trioxa-3-azatetradecan-14-yl) oxy)-4-(4-methylthiazol-5-yl)benzyl)-1-((S)-2-(1-fluorocyclopropane-1carboxamido)-3,3-dimethylbutanoyl)-4-hydroxypyrrolidine-2-carboxamide (18a)

Starting from compound 17a (13 mg, $0.0167 \mathrm{mmol})$ and following the general method $\mathbf{B}$ the deprotected carboxylic acid derivative was obtained in quantitative yield $(12 \mathrm{mg})$. Starting from the crude carboxylic acid ( $0.0166 \mathrm{mmol}, 1$ eq.) and following the general method $\mathrm{H}$, the desired compound was obtained (4 mg, yield: $23 \%) .{ }^{1} \mathrm{H}$ NMR $\left(500 \mathrm{MHz}, \mathrm{CDCl}_{3}\right)$ 8: $8.65(\mathrm{~s}, 1 \mathrm{H}), 7.47-7.43(\mathrm{~m}, 1 \mathrm{H}), 7.32-7.29(\mathrm{~m}$, $1 \mathrm{H}), 7.06$ (dd, $J=2.4,7.2 \mathrm{~Hz}, 1 \mathrm{H}), 6.99-6.94(\mathrm{~m}, 2 \mathrm{H}), 6.88-6.86(\mathrm{~m}$, $1 \mathrm{H}), 4.90-4.79(\mathrm{~m}, 1 \mathrm{H}), 4.65-4.59(\mathrm{~m}, 1 \mathrm{H}), 4.56(\mathrm{t}, J=9.0 \mathrm{~Hz}, 1 \mathrm{H})$, $4.49-4.39$ (m, 3H), 4.22-4.11 (m, 2H), 3.96-3.43 (m, 18H), 2.84-2.61 $(\mathrm{m}, 3 \mathrm{H}), 2.50(\mathrm{~d}, J=2.7 \mathrm{~Hz}, 3 \mathrm{H}), 2.38-2.30(\mathrm{~m}, 1 \mathrm{H}), 2.14-2.04(\mathrm{~m}$, $2 \mathrm{H}), 1.37-1.18(\mathrm{~m}, 4 \mathrm{H}), 0.96$ (d, $J=1.8 \mathrm{~Hz}, 9 \mathrm{H}) ;{ }^{13} \mathrm{C}-\mathrm{NMR}(126 \mathrm{MHz}$, $\mathrm{CDCl}_{3}$ ) $\delta: 171.3,171.1,171.0,170.9,170.3170 .1,169.5,169.0,168.8$, $167.7,156.8,150.4,148.7,146.9,136.3,132.7,132.5,131.8,130.0$, $129.8,127.1,127.0,122.3,122.2,116.9,113.0,112.9,112.0,110.5$, 79.6, 71.0, 70.8, 70.7, 70.5, 70.3, 70.2, 69.8, 68.1, 59.0, 58.9, 57.6, $56.8,49.1,49.1,42.1,39.2,39.2,38.7,38.7,36.8,35.7,35.6,31.6$, 26.5, 23.0, 22.9, 16.3, 13.9 (d, $\left.{ }^{2} J=10.0 \mathrm{~Hz}\right), 13.8\left(\mathrm{~d},{ }^{2} J=10.0 \mathrm{~Hz}\right)$. HRMS: calculated for $\mathrm{C}_{49} \mathrm{H}_{62} \mathrm{FN}_{8} \mathrm{O}_{13} \mathrm{~S}[\mathrm{M}+\mathrm{H}]^{+}: m / z=1021.4136$; observed: $m / z=1021.4480$.

4.1.31. Tert-butyl-17-hydroxy-3,6,9,12,15-pentaoxaheptadecanoate (15b)

Starting from pentaethylene glycol $(7.32 \mathrm{~g}, 31 \mathrm{mmol})$ and following the general method $\mathrm{C}$, the title compound was obtained. Yield: $600 \mathrm{mg}$ (44\%). Analytical data matched with those previously reported. ${ }^{31}$

\subsubsection{Tert-butyl-17-iodo-3,6,9,12,15-pentaoxaheptadecanoate (16b)}

Starting from compound 15b (400 mg, $1.14 \mathrm{mmol}$ ) and following the general method $\mathrm{D}$, the title compound was obtained. Yield: $402 \mathrm{mg}$ (81\%). ${ }^{1} \mathrm{H}$ NMR $\left(500 \mathrm{MHz}, \mathrm{CDCl}_{3}\right) \delta: 4.05$ (s, 2H), 3.81-3.69 (m, 18H), $3.29(\mathrm{t}, J=6.9 \mathrm{~Hz}, 2 \mathrm{H}), 1.50(\mathrm{~s}, 9 \mathrm{H}) .{ }^{13} \mathrm{C}$ NMR $\left(126 \mathrm{MHz}, \mathrm{CDCl}_{3}\right) \delta$ : 169.7, 81.5, 72.0, 70.8, 70.7, 70.7, 70.6, 70.3, 69.1, 28.1.
4.1.33. 17-(2-(( (2S,4R)-1-((S)-2-(1-fluorocyclopropane-1-carboxamido)3,3-dimethylbutanoyl)-4-hydroxypyrrolidine-2-carboxamido)methyl)-5-(4methylthiazol-5-yl)phenoxy)-3,6,9,12,15-pentaoxaheptadecanoic acid (17b)

Starting from compound 2 ( $40 \mathrm{mg}, 0.075 \mathrm{mmol}, 1$ eq.), 16b (42 mg, 0.09 mmol, 1.2 eq.) and $\mathrm{K}_{2} \mathrm{CO}_{3}(31 \mathrm{mg}, 0.22,3$ eq.), and following the general method $\mathrm{I}$, the titled compound was obtained $(29 \mathrm{mg}$, yield: $48 \%$ ). ${ }^{1} \mathrm{H}$ NMR $\left(500 \mathrm{MHz}, \mathrm{CDCl}_{3}\right.$ ) $\delta: 8.64$ (s, $\left.1 \mathrm{H}\right), 7.02$ (dd, $J=3.6$, $8.8 \mathrm{~Hz}, 1 \mathrm{H}), 6.94$ (dd, $J=1.6,7.7 \mathrm{~Hz}, 1 \mathrm{H}), 6.87(\mathrm{~d}, J=1.4 \mathrm{~Hz}, 1 \mathrm{H}$ ), $4.63(\mathrm{t}, J=8.1 \mathrm{~Hz}, 1 \mathrm{H}), 4.54-4.42(\mathrm{~m}, 4 \mathrm{H}), 4.22-4.12(\mathrm{~m}, 2 \mathrm{H}), 3.97$ (s, $2 \mathrm{H}), 3.93-3.83(\mathrm{~m}, 3 \mathrm{H}), 3.75-3.60(\mathrm{~m}, 17 \mathrm{H}), 2.49$ (s, 3H), 2.39-2.33 (m, 1H), 2.10-2.06 (m, 1H), 1.43 (s, 9H), 1.31-1.20 (m, 4H), 0.93 (s, $9 \mathrm{H}) ;{ }^{13} \mathrm{C}$ NMR $\left(101 \mathrm{MHz}, \mathrm{CDCl}_{3}\right) \quad \delta: 170.8,170.7,170.0$ (d, $\left.{ }^{2} J=20.3 \mathrm{~Hz}\right), 169.8,157.0,150.4,148.6,132.4,131.8,129.9,127.1$, 122.1, 113.0, 81.7, 79.5, 70.9, 70.7, 70.3, 69.8, 69.2, 68.1, 58.8, 57.5, $56.7,39.2,36.6,35.8,28.2,26.5,16.2,13.7$ (t, $\left.{ }^{2} J=9.6 \mathrm{~Hz}\right)$. MS: calculated for $\mathrm{C}_{42} \mathrm{H}_{64} \mathrm{FN}_{4} \mathrm{O}_{12} \mathrm{~S}[\mathrm{M}+\mathrm{H}]^{+}: \mathrm{m} / z=867.4$; observed: $m$ / $z=867.7$.

\subsubsection{4. (2S, 4R)-N-(2-((1-((2-(2,6-dioxopiperidin-3-yl)-1,3-} dioxoisoindolin-4-yl)amino)-4-oxo-6,9,12,15,18-pentaoxa-3-azaicosan20-yl)oxy)-4-(4-methylthiazol-5-yl)benzyl)-1-((S)-2-(1-

fluorocyclopropane-1-carboxamido)-3,3-dimethylbutanoyl)-4hydroxypyrrolidine-2-carboxamide (18b)

Starting from compound $17 \mathrm{~b}(29 \mathrm{mg}, 0.033 \mathrm{mmol})$ and following the general method $\mathbf{B}$ the deprotected carboxylic acid derivative was obtained in quantitative yield $(27 \mathrm{mg})$. Starting from the crude carboxylic acid ( $27 \mathrm{mg}, 0.033,1$ eq.) and following the general method $\mathrm{H}$, the desired compound was obtained $(4.2 \mathrm{mg}$, yield: $11 \%) .{ }^{1} \mathrm{H}$ NMR $\left(500 \mathrm{MHz}, \mathrm{CDCl}_{3}\right) \delta: 8.65(\mathrm{~s}, 1 \mathrm{H}), 7.47(\mathrm{t}, J=7.6 \mathrm{~Hz}, 1 \mathrm{H}), 7.31(\mathrm{~d}$, $J=7.6 \mathrm{~Hz}, 1 \mathrm{H}), 7.07$ (dd, $J=1.4,7.0 \mathrm{~Hz}, 1 \mathrm{H}), 7.00$ (dd, $J=1.4$, $8.5 \mathrm{~Hz}, 1 \mathrm{H}), 6.94(\mathrm{~d}, J=7.6 \mathrm{~Hz}, 1 \mathrm{H}), 6.87(\mathrm{~d}, J=1.5 \mathrm{~Hz}, 1 \mathrm{H})$, $4.90-4.82(\mathrm{~m}, 1 \mathrm{H}), 4.63$ (dt, $J=3.2,7.8 \mathrm{~Hz}, 1 \mathrm{H}), 4.55$ (d, $J=9.1 \mathrm{~Hz}$, $1 \mathrm{H}), 4.50-4.42(\mathrm{~m}, 3 \mathrm{H}), 4.21-4.10(\mathrm{~m}, 2 \mathrm{H}), 3.95(\mathrm{~s}, 2 \mathrm{H}), 3.95-3.43(\mathrm{~m}$, $24 \mathrm{H}), 2.92-2.62(\mathrm{~m}, 3 \mathrm{H}), 2.50$ (s, 3H), 2.39-2.31 (m, 1H), 2.15-2.04 (m, 2H), $1.35-1.18(\mathrm{~m}, 4 \mathrm{H}), 0.94(\mathrm{~d}, J=1.8 \mathrm{~Hz}, 9 \mathrm{H}) .{ }^{13} \mathrm{C}$ NMR $\left(500 \mathrm{MHz}, \quad \mathrm{CDCl}_{3}\right) \quad \delta: \quad 171.4, \quad 171.3, \quad 171.2, \quad 170.9, \quad 170.8$, $170.1\left(\mathrm{~d},{ }^{2} J=20.5 \mathrm{~Hz}\right), 169.5,168.8,168.7,167.7,157.0,150.4,148.7$, 147.0, 136.3, 132.7, 132.4, 131.8, 130.1, 127.1, 122.2, 117.0, 113.0, $111.9,110.5,79.3,71.1,70.9,70.7,70.6,70.5,70.5,70.2,69.8,68.2$, $58.9,57.6,56.8,49.1,42.1,39.2,38.6,36.8,35.7,31.6,26.5,22.9$, $16.3,13.8\left(\mathrm{~d},{ }^{2} J=10.2 \mathrm{~Hz}\right), 13.7\left(\mathrm{~d},{ }^{2} J=10.2 \mathrm{~Hz}\right)$ HRMS: calculated for $\mathrm{C}_{53} \mathrm{H}_{70} \mathrm{FN}_{8} \mathrm{O}_{15} \mathrm{~S}[\mathrm{M}+\mathrm{H}]^{+}: \quad m / z=1109.4660 ; \quad$ observed: $\mathrm{m} /$ $z=1110.4625$.

4.1.35. Methyl-5-(2-(((2S,4R)-1-((S)-2-(1-fluorocyclopropane-1carboxamido)-3,3-dimethylbutanoyl)-4-hydroxypyrrolidine-2carboxamido)methyl)-5-(4-methylthiazol-5-yl)phenoxy)pentanoate (17c)

Starting from compound 2 ( $40 \mathrm{mg}, 0.075 \mathrm{mmol}, 1$ eq.), methyl 5bromobutanoate $16 \mathrm{c}\left(21 \mathrm{mg}, 0.113 \mathrm{mmol}, 1.5\right.$ eq.) and $\mathrm{K}_{2} \mathrm{CO}_{3}(31 \mathrm{mg}$, 0.22 , 3 eq.), and following the general method $\mathrm{I}$, the titled compound was obtained ( $30 \mathrm{mg}$, yield: $62 \%) .{ }^{1} \mathrm{H}$ NMR $\left(500 \mathrm{MHz}, \mathrm{CDCl}_{3}\right) 8: 8.66$ (s, $1 \mathrm{H}$ ), 7.03 (dd, $J=3.5,8.8 \mathrm{~Hz}, 1 \mathrm{H}$ ), 6.92 (dd, $J=1.5,7.7 \mathrm{~Hz}, 1 \mathrm{H}), 6.82$ (d, $J=1.5 \mathrm{~Hz}, 1 \mathrm{H}), 4.69$ (t, $J=7.8 \mathrm{~Hz}, 1 \mathrm{H}), 4.54-4.45(\mathrm{~m}, 3 \mathrm{H}), 4.38$ (dd, $J=5.5,14.9 \mathrm{~Hz}, 1 \mathrm{H}), 4.05-3.96(\mathrm{~m}, 2 \mathrm{H}), 3.96-3.91(\mathrm{~m}, 1 \mathrm{H}), 3.64$ (s, 3H), 3.61 (dd, $J=4.2,11.2 \mathrm{~Hz}, 1 \mathrm{H}), 2.52-2.45(\mathrm{~m}, 4 \mathrm{H}), 2.40$ (t, $J=6.8 \mathrm{~Hz}, 2 \mathrm{H}), 2.09-2.04(\mathrm{~m}, 1 \mathrm{H}), 1.91-1.78(\mathrm{~m}, 4 \mathrm{H}), 1.33-1.24(\mathrm{~m}$, $4 \mathrm{H}), 0.91(\mathrm{~s}, 9 \mathrm{H}) ;{ }^{13} \mathrm{C}$ NMR $\left(101 \mathrm{MHz}, \mathrm{CDCl}_{3}\right) \delta: 173.9,171.0,170.3(\mathrm{~d}$, $\left.{ }^{2} J=20.5 \mathrm{~Hz}\right), 170.2,156.8,150.4,148.6,132.4,131.9,129.7,126.4$, $121.7,112.1,79.5,70.3,67.7,58.6,57.5,56.6,51.7,38.9,36.0,35.5$, 33.7, 28.8, 26.4, 21.8, 16.2, $13.8\left(\mathrm{~d},{ }^{2} J=3.7 \mathrm{~Hz}\right), 13.7\left(\mathrm{~d},{ }^{2} J=3.7 \mathrm{~Hz}\right)$. MS: calculated for $\mathrm{C}_{32} \mathrm{H}_{44} \mathrm{FN}_{4} \mathrm{O}_{7} \mathrm{~S}[\mathrm{M}+\mathrm{H}]^{+}: m / z=647.3$; observed: $m / z=647.7$. 
4.1.36. (2S, 4R)-N-(2-((5-((2-((2-(2,6-dioxopiperidin-3-yl)-1,3dioxoisoindolin-4-yl)amino)ethyl)amino)-5-oxopentyl)oxy)-4-(4methylthiazol-5-yl)benzyl)-1-((S)-2-(1-fluorocyclopropane-1carboxamido)-3,3-dimethylbutanoyl)-4-hydroxypyrrolidine-2-carboxamide (18c)

Compound 17c (30 mg, $0.046 \mathrm{mmol}, 1$ eq.) was dissolved in a mixture of THF $(2 \mathrm{~mL})$ and water $(0.50 \mathrm{~mL})$. Then $\mathrm{LiOH}$ was added ( $2.2 \mathrm{mg}, 0.0928 \mathrm{mmol}, 2$ eq.) and the mixture was stirred at r.t. for $2 \mathrm{~h}$. LC-MS analysis (acidic method) showed complete conversion of the starting material. A solution of $\mathrm{HCl} 4 \mathrm{~N}$ in dioxane was added to $\mathrm{pH}<6$ and the mixture was evaporated to dryness to yield the deprotected carboxylic acid derivative (25 mg, yield: quantitative). Starting from the crude carboxylic acid $(0.023 \mathrm{mmol}, 1$ eq.) and following the general method $\mathbf{H}$, the desired compound was obtained (5 mg, yield: $22 \%$ ). ${ }^{1} \mathrm{H}$ NMR (500 MHz, $\mathrm{CDCl}_{3}$ ) $\delta: 8.66(\mathrm{~s}, 1 \mathrm{H}), 7.47(\mathrm{t}$, $J=7.9 \mathrm{~Hz}, 1 \mathrm{H}), 7.29(\mathrm{dd}, J=2.2,7.7 \mathrm{~Hz}, 1 \mathrm{H}), 7.07(\mathrm{~d}, J=7.2 \mathrm{~Hz}$, $1 \mathrm{H}), 6.97$ (dd, $J=3.1,8.6 \mathrm{~Hz}, 1 \mathrm{H}), 6.95-6.94(\mathrm{~m}, 1 \mathrm{H}), 6.85-6.83(\mathrm{~m}$, $1 \mathrm{H}$ ), $4.90-4.80$ (m, 1H), 4.68 (ddd, $J=7.7,7.7,1.9 \mathrm{~Hz}, 1 \mathrm{H}$ ), $4.55-4.45$ (m, 3H), 4.38-4.30 (m, 1H), 4.05-3.93 (m, 3H), 3.60 (qd, $J=1.9$, $11.2 \mathrm{~Hz}, 1 \mathrm{H}), 3.47-3.36(\mathrm{~m}, 4 \mathrm{H}), 2.85-2.60$ (m, 3H), 2.50 (s, 3H), 2.47-2.40 (m, 1H), 2.34-2.25 (m, 2H), 2.11-2.02 (m, 2H), 1.90-1.81 $(\mathrm{m}, 4 \mathrm{H}), 1.36-1.17(\mathrm{~m}, 4 \mathrm{H}), 0.90(\mathrm{~d}, J=3.1 \mathrm{~Hz}, 9 \mathrm{H}) ;{ }^{13} \mathrm{C}$ NMR $\left(126 \mathrm{MHz}, \mathrm{CDCl}_{3}\right) \delta: 173.9,171.4,171.2,170.5,170.4,170.3,169.7$, 169.6, 169.0, 168.9, 167.6, 156.9, 150.4, 148.7, 147.0, 136.4, 132.7, $131.8,130.2,130.1,126.2,121.8,121.8,117.0,112.3,112.1,79.4$, $70.3,67.9,58.8,57.7,56.8,56.7,49.2,49.1,42.3,39.3,39.2,39.1$, $36.4,36.1,35.5,31.6,28.8,28.7,26.5,22.9,16.3,13.9$ (d, $\left.{ }^{2} J=3.7 \mathrm{~Hz}\right), 13.8\left(\mathrm{~d},{ }^{2} J=3.7 \mathrm{~Hz}\right)$. HRMS analysis: calculated for $\mathrm{C}_{46} \mathrm{H}_{56} \mathrm{FN}_{8} \mathrm{O}_{10} \mathrm{~S} \quad[\mathrm{M}+\mathrm{H}]^{+}: \quad m / z=931.3819 ; \quad$ observed: $\quad m /$ $z=931.3823$.

\subsubsection{7. (2S,4R)-1-((R)-2-(1-fluorocyclopropane-1-carboxamido)-3-} mercapto-3-methylbutanoyl)-4-hydroxy- $N$-(4-(4-methylthiazol-5-yl) benzyl)pyrrolidine-2-carboxamide (20)

To a solution of compound $19(0.042 \mathrm{mmol})$, HATU (16 mg, $0.042 \mathrm{mmol}$ ), HOAT $(5.71 \mathrm{mg}, 0.042 \mathrm{mmol})$ 1-fluorocyclopropane-1carboxylic acid $(4.3 \mathrm{mg}, 0.042 \mathrm{mmol})$ in DMF $(1 \mathrm{~mL})$, DIPEA $(25 \mu \mathrm{L}$, $0.141 \mathrm{mmol}$ ) was added. The reaction mixture was stirred at r.t. for $30 \mathrm{~min}$. LC-MS analysis (acidic method) showed complete conversion of the starting material. Water $(1 \mathrm{~mL})$ was added and the resulting mixture was extracted with DCM $(3 \times 5 \mathrm{~mL})$. After drying the organic phase over $\mathrm{MgSO}_{4}$ and the solvent was removed under reduced pressure to afford the title compound ( $28.3 \mathrm{mg}, 85 \%$ yield) which was used without further purification. ${ }^{1} \mathrm{H}$ NMR $\left(400 \mathrm{MHz}, \mathrm{CDCl}_{3}\right) \delta 8.71 \quad(\mathrm{~s}, 1 \mathrm{H})$, 7.54-7.51 (m, 6H), 7.34-7.31 (m, 3H), 7.25-7.19 (m, 12H), 4.69-4.64 (m, $1 \mathrm{H}), 4.38-4.36(\mathrm{~m}, 1 \mathrm{H}), 4.32-4.19(\mathrm{~m}, 2 \mathrm{H}), 3.66(\mathrm{~d}, J=4.2 \mathrm{~Hz}$, $1 \mathrm{H}$ ), 3.50 (d, $J=11.6 \mathrm{~Hz}, 1 \mathrm{H}$ ), 3.26 (dd, $J=3.9,11.6 \mathrm{~Hz}, 1 \mathrm{H}$ ), 3.09 (d, $J=5.9 \mathrm{~Hz}, 1 \mathrm{H}$ ), 2.41-2.33 (m, 1H), 2.14-2.07 (m, 1H), 1.38-1.21 (m, $7 \mathrm{H}), 0.97$ (s, 3H). ${ }^{19} \mathrm{~F}$ NMR: -197.41 . MS analysis: calculated for $\mathrm{C}_{44} \mathrm{H}_{45} \mathrm{FN}_{4} \mathrm{O}_{4} \mathrm{~S}_{2}$ : 776.3; observed: $777.3[\mathrm{M}+\mathrm{H}]^{+}$.

The trityl protected compound $(0.04 \mathrm{mmol})$ was dissolved in $1.8 \mathrm{~mL}$ of DCM. TIPS $(0.1 \mathrm{~mL})$ and TFA $(0.1 \mathrm{~mL})$ were added, and the mixture was left to react at r.t. for $2 \mathrm{~h}$. LC-MS analysis (acidic method) showed complete conversion of the starting material. Volatiles were removed and the crude was dissolved in $\mathrm{MeOH}$, filtered and purified by preparative HPLC and freeze-dried to give pure deprotected compound as white solid (16 mg, 79\% yield). ${ }^{1} \mathrm{H}$ NMR $\left(500 \mathrm{MHz}, \mathrm{CDCl}_{3}\right) \delta: 8.72$ (s, $1 \mathrm{H}$ ), 7.44 (br.s, $1 \mathrm{H}$ ), 7.39 (d, $J=9.4 \mathrm{~Hz}, 2 \mathrm{H}), 7.36$ (d, $J=7.8 \mathrm{~Hz}, 2 \mathrm{H}$ ), 7.15 (br. s, $1 \mathrm{H}), 4.71$ (t, $J=7.9 \mathrm{~Hz}, 1 \mathrm{H}), 4.64(\mathrm{~d}, J=8.5 \mathrm{~Hz}, 1 \mathrm{H})$, $4.60-4.55$ (m, 2H), 4.36 (dd, $J=5.3,14.8 \mathrm{~Hz}, 1 \mathrm{H}), 4.15-4.12(\mathrm{~m}, 1 \mathrm{H})$, 3.74 (dd, $J=3.5,11.3 \mathrm{~Hz}, 1 \mathrm{H}$ ), 2.70 (s, $1 \mathrm{H}$ ), 2.60 (s, $1 \mathrm{H}$ ), 2.53-2.46 (m, 4H), 2.20-2.13 (m, 1H), 1.39-1.30 (m, 10H). ${ }^{19} \mathrm{~F}$ NMR: -197.80. ${ }^{13} \mathrm{C}$ NMR $\left(101 \mathrm{mHz}, \mathrm{CDCl}_{3}\right): 169.7\left(\mathrm{~d},{ }^{2} J=20.7 \mathrm{~Hz}\right), 169.4,169.2$, 169.5, 147.3, 137.0, 130.0, 128.7, 127.2, 77.05 (d, ${ }^{1} J=232.0 \mathrm{~Hz}$ ), $69.1,57.9,56.6,55.5,45.0,42.3,35.3,29.5,27.7,14.9,13.0$ (d, $\left.{ }^{2} J=10.6 \mathrm{~Hz}\right), \quad 12.8 \quad\left(\mathrm{~d}, \quad{ }^{2} J=10.5 \mathrm{~Hz}\right) . \quad$ MS: calculated for
$\mathrm{C}_{25} \mathrm{H}_{31} \mathrm{FN}_{4} \mathrm{O}_{4} \mathrm{~S}_{2}[\mathrm{M}+\mathrm{H}]^{+}: m / z=535.2$; observed: $m / z=535.2$.

4.1.38. Tert-butyl(R)-1-(1-fluorocyclopropyl)-3-((2S,4R)-4-hydroxy-2((4-(4-methylthiazol-5-yl)benzyl)carbamoyl)pyrrolidine-1-carbonyl)-4,4dimethyl-1-oxo-8,11,14-trioxa-5-thia-2-azahexadecan-16-oate (21a)

Starting from compound 20 ( $20 \mathrm{mg}, 0.037 \mathrm{mmol}, 1 \mathrm{eq}$ ), 16a ( $15 \mathrm{mg}, 0.041 \mathrm{mmol}, 1.1$ eq.) and $\mathrm{DBU}(6,3 \mu \mathrm{L}, 0.041,1.1 \mathrm{eq}$.$) , and$ following the general method G, compound 21a was obtained $(15 \mathrm{mg}$, yield: $46 \%) .{ }^{1} \mathrm{H} \mathrm{NMR}\left(400 \mathrm{MHz}, \mathrm{CDCl}_{3}\right) \delta: 8.64$ (s, $\left.1 \mathrm{H}\right), 7.33$ (dd, $J=8.1,14.2 \mathrm{~Hz}, 4 \mathrm{H}), 4.78(\mathrm{~d}, J=8.3 \mathrm{~Hz}, 1 \mathrm{H}), 4.74(\mathrm{t}, J=7.6 \mathrm{~Hz}, 1 \mathrm{H})$, $4.53-4.49$ (m, 1H), 4.42 (ddt, $J=6.0,13.9,13.2 \mathrm{~Hz}, 2 \mathrm{H}), 3.96(\mathrm{~s}, 2 \mathrm{H})$, $3.96-3.91(\mathrm{~m}, 1 \mathrm{H}), 3.81$ (dd, $J=4.2,11.1 \mathrm{~Hz}, 1 \mathrm{H}), 3.68-3.43(\mathrm{~m}$, $10 H), 2.79-2.64$ (m, 2H), 2.49 (s, 3H), 2.44-2.36 (m, 1H), 2.23-2.15 (m, 1H), 1.44 (s, 9H), 1.35-1.24 (m, 10H); ${ }^{13} \mathrm{C}$ NMR (101 MHz, $\mathrm{CDCl}_{3}$ ) $\delta: 170.8,170.2\left(\mathrm{~d},{ }^{2} J=20.7 \mathrm{~Hz}\right), 169.8,169.6,150.2,148.5,138.1$, 131.6, 131.0, 129.5, 128.3, 128.2, 81.7, 79.3, 77.3, 77.0, 76.7, 70.7, 70.5, 70.5, 70.4, 70.2, 69.9, 69.0, 59.1, 56.4, 56.0, 47.9, 43.0, 36.8, 28.4, 28.1, 25.8, 25.1, 16.1, $13.9\left(\mathrm{~d},{ }^{2} J=4.8 \mathrm{~Hz}\right), 13.8\left(\mathrm{~d},{ }^{2} J=4.8 \mathrm{~Hz}\right)$. MS: calculated for $\mathrm{C}_{37} \mathrm{H}_{54} \mathrm{FN}_{4} \mathrm{O}_{9} \mathrm{~S}_{2}[\mathrm{M}+\mathrm{H}]^{+}: m / z=781.3$; observed: $m / z=781.8$.

\subsubsection{9. (2S,4R)-1-((17R)-1-((2-(2,6-dioxopiperidin-3-yl)-1,3-} dioxoisoindolin-4-yl)amino)-17-(1-fluorocyclopropane-1-carboxamido)16,16-dimethyl-4-oxo-6,9,12-trioxa-15-thia-3-azaoctadecan-18-oyl)-4hydroxy-N-(4-(4-methylthiazol-5-yl)benzyl)pyrrolidine-2-carboxamide (22a)

Starting from compound 21a (15 mg, $0.019 \mathrm{mmol}$ ) and following the general method $\mathbf{B}$ the deprotected carboxylic acid derivative was obtained in quantitative yield $(13.9 \mathrm{mg})$. Starting from the crude carboxylic acid $(0.019,1$ eq.) and following the general method $\mathbf{H}$, the desired compound was obtained (11 mg, yield: $56 \%$ ). ${ }^{1} \mathrm{H}$ NMR (400 MHz, MeOD) $\delta: 8.86$ (s, $1 \mathrm{H}), 7.55$ (dd, $J=7.2,8.5 \mathrm{~Hz}, 1 \mathrm{H}$ ), $7.46-7.40(\mathrm{~m}, 4 \mathrm{H}), 7.13(\mathrm{~d}, J=9.0 \mathrm{~Hz}, 1 \mathrm{H}), 7.05(\mathrm{~d}, J=7.5 \mathrm{~Hz}, 1 \mathrm{H})$, 5.04 (dd, $J=5.6,12.8 \mathrm{~Hz}, 1 \mathrm{H}), 4.93(\mathrm{~s}, 1 \mathrm{H}), 4.60(\mathrm{t}, J=8.4 \mathrm{~Hz}, 1 \mathrm{H})$, 4.54-4.35 (m, 3H), 3.95 (s, 2H), $3.88(\mathrm{~d}, J=3.1 \mathrm{~Hz}, 2 \mathrm{H}), 3.59-3.45$ (m, 14H), 2.89-2.65 (m, 5H), $2.47(\mathrm{~s}, 3 \mathrm{H}), 2.28-2.23(\mathrm{~m}, 1 \mathrm{H})$, $2.14-2.06$ (m, 2H), 1.42-1.25 (m, 10H); ${ }^{13} \mathrm{C}$ NMR (101 MHz, MeOD) $\delta$ : 174.6, 174.0, 173.5, 171.6, $171.5\left(\mathrm{~d},{ }^{2} J=21.2 \mathrm{~Hz}\right) 171.4,170.8$, 170.6, 169.3, 152.8, 149.1, 148.2, 140.2, 137.3, 134.0, 133.4, 131.6, 130.4, 129.0, 118.1, 112.2, 111.6, 79.1 (d, ${ }^{1} \mathrm{~J}=231.9 \mathrm{~Hz}$ ), 72.0, 71.7, $71.4,71.3,71.1,71.0,61.1,58.1,57.2,50.2,43.7,42.5,39.5,39.0$, $32.2,29.6,27.0,25.7,23.8,15.9,14.2,14.1\left(\mathrm{t},{ }^{2} J=9.5 \mathrm{~Hz}\right)$. HRMS analysis: calculated for $\mathrm{C}_{48} \mathrm{H}_{60} \mathrm{FN}_{8} \mathrm{O}_{12} \mathrm{~S}_{2}[\mathrm{M}+\mathrm{H}]^{+}: m / z=1023.3751$; observed: $m / z=1023.3730$.

4.1.40. Tert-butyl(R)-1-(1-fluorocyclopropyl)-3-((2S,4R)-4-hydroxy-2((4-(4-methylthiazol-5-yl)benzyl)carbamoyl)pyrrolidine-1-carbonyl)-4,4dimethyl-1-oxo-8, 11,14,17,20-pentaoxa-5-thia-2-azadocosan-22-oate (21b)

Starting from compound 20 ( $20 \mathrm{mg}, 0.037 \mathrm{mmol}, 1$ eq.), $\mathbf{1 6 b}$ (19 mg, $0.041 \mathrm{mmol}, 1.1$ eq.) and DBU $(6,3 \mu \mathrm{L}, 0.041,1.1$ eq.), and following the general method $\mathbf{G}$, the titled compound was obtained (19.4 mg, yield: 66\%). ${ }^{1} \mathrm{H}$ NMR (400 MHz, $\mathrm{CDCl}_{3}$ ) $\delta: 8.65$ (s, $\left.1 \mathrm{H}\right), 7.34$ (dd, $J=8.3,13.6 \mathrm{~Hz}, 4 \mathrm{H}), 4.81(\mathrm{~d}, J=8.5 \mathrm{~Hz}, 1 \mathrm{H}), 4.74(\mathrm{t}, J=7.7 \mathrm{~Hz}$, $1 \mathrm{H}), 4.53-4.50(\mathrm{~m}, 1 \mathrm{H}), 4.42$ (ddt, $J=5.8,15.2,15.3 \mathrm{~Hz}, 2 \mathrm{H}), 3.98$ (s, $2 \mathrm{H}), 3.94-3.80$ (m, 2H), 3.70-3.42 (m, 18H), 2.80-2.64 (m, 2H), 2.49 (s, 3H), 2.43-2.36 (m, 1H), 2.24-2.15 (m, 1H), 1.44 (s, 9H), 1.33-1.24 $(\mathrm{m}, 10 H) ;{ }^{13} \mathrm{C}$ NMR $\left(101 \mathrm{MHz}, \mathrm{CDCl}_{3}\right) \delta: 171.0,170.3\left(\mathrm{~d},{ }^{2} J=20.5 \mathrm{~Hz}\right)$, 169.9, 169.8, 150.4, 148.6, 138.3, 131.7, 131.1, 129.6, 128.3, 81.7, 79.4, 70.9, 70.7, 70.6, 70.3, 70.0, 69.2, 59.3, 56.5, 56.0, 48.1, 43.2, $37.0,28.6,28.3,25.9,25.2,16.2,14.0\left(\mathrm{~d},{ }^{2} J=2.9 \mathrm{~Hz}\right), 13.9$ (d, ${ }^{2} J=2.9 \mathrm{~Hz}$ ). MS: calculated for $\mathrm{C}_{41} \mathrm{H}_{62} \mathrm{FN}_{4} \mathrm{O}_{11} \mathrm{~S}_{2}[\mathrm{M}+\mathrm{H}]^{+}: \mathrm{m} /$ $z=869.4$; observed: $m / z=869.3$. 
4.1.41. (2S,4R)-1-((17R)-1-((2-(2,6-dioxopiperidin-3-yl)-1,3dioxoisoindolin-4-yl)amino)-17-(1-fluorocyclopropane-1-carboxamido)16,16-dimethyl-4-oxo-6,9,12-trioxa-15-thia-3-azaoctadecan-18-oyl)-4hydroxy-N-(4-(4-methylthiazol-5-yl)benzyl)pyrrolidine-2-carboxamide (22b)

Starting from compound 21b (19.4 mg, $0.022 \mathrm{mmol})$ and following the general method $\mathbf{B}$ the deprotected carboxylic acid derivative was obtained in quantitative yield ( $17 \mathrm{mg}$, yield: quantitative). Starting from the crude carboxylic acid $(0.011 \mathrm{mmol}, 1 \mathrm{eq}$.) and following the general method $\mathbf{H}$, the desired compound was obtained $(7.3 \mathrm{mg}$, yield: 47\%). ${ }^{1} \mathrm{H}$ NMR (500 MHz, MeOD) $\delta: 8.86$ (s, $1 \mathrm{H}$ ), 7.55 (dd, $J=7.2$, $8.6 \mathrm{~Hz}, 1 \mathrm{H}), 7.44$ (dd, $J=8.5,11.4 \mathrm{~Hz}, 4 \mathrm{H}), 7.14(\mathrm{~d}, J=8.6 \mathrm{~Hz}, 1 \mathrm{H})$, 7.05 (d, $J=7.0 \mathrm{~Hz}, 1 \mathrm{H}$ ), 5.04 (dd, $J=5.4,12.4 \mathrm{~Hz}, 1 \mathrm{H}$ ), 4.94 (s, $1 \mathrm{H}$ ), 4.61 (t, $J=8.4 \mathrm{~Hz}, 1 \mathrm{H}), 4.52-4.37(\mathrm{~m}, 3 \mathrm{H}), 3.96(\mathrm{~s}, 2 \mathrm{H}), 3.92-3.86(\mathrm{~m}$, $2 \mathrm{H}), 3.57-3.47$ (m, 22H), 2.88-2.66 (m, 5H), 2.48 (s, 3H), 2.28-2.24 (m, 1H), 2.14-2.07 (m, 2H), 1.42-1.27 (m, 10H); ${ }^{13} \mathrm{C}$ NMR $(126 \mathrm{MHz}$, MeOD) $\delta: 174.7,174.1,173.6,171.5\left(\mathrm{~d},{ }^{2} J=19.8 \mathrm{~Hz}\right) 171.5,170.8$, 170.6, 169.2, 152.9, 149.1, 148.1, 140.2, 137.3, 134.0, 133.4, 131.6, $130.5, \quad 130.4,129.6, \quad 129.0, \quad 118.1, \quad 112.1, \quad 111.5,79.1 \quad(d$, $\left.{ }^{1} J=231.2 \mathrm{~Hz}\right), 72.0,71.6,71.6,71.5,71.4,71.3,71.1,71.0,61.1$, 58.1, 57.1, 43.6, 42.5, 39.4, 39.1, 32.2, 29.6, 26.9, 25.7, 23.8, 15.9, $14.2\left(\mathrm{~d},{ }^{2} J=7.9 \mathrm{~Hz}\right), 14.1$ (d, ${ }^{2} J=7.9 \mathrm{~Hz}$ ). HRMS: calculated for $\mathrm{C}_{52} \mathrm{H}_{68} \mathrm{FN}_{8} \mathrm{O}_{14} \mathrm{~S}_{2} \quad\left[\mathrm{M}+\mathrm{H}^{+}: \quad m / z=1111.4275 ; \quad\right.$ observed: $m /$ $z=1111.4052$

\subsubsection{Methyl-5-(( $(R)-3-(1-f l u o r o c y c l o p r o p a n e-1-c a r b o x a m i d o)-4$} ((2S,4R)-4-hydroxy-2-((4-(4-methylthiazol-5-yl)benzyl)carbamoyl) pyrrolidin-1-yl)-2-methyl-4-oxobutan-2-yl)thio)pentanoate (21c)

Starting from compound 20 ( $20 \mathrm{mg}, 0.037 \mathrm{mmol}, 1 \mathrm{eq}$ ), methyl 5bromobutanoate $16 \mathrm{c}$ ( $8 \mathrm{mg}, 0.041 \mathrm{mmol}, 1.1$ eq.) and DBU $(6,3 \mu \mathrm{L}$, $0.041,1.1$ eq.), and following the general method $\mathbf{G}$, compound 21c was obtained (16.5 mg, yield: $67 \%) .{ }^{1} \mathrm{H}$ NMR $\left(400 \mathrm{MHz}, \mathrm{CDCl}_{3}\right)$ 8: 8.65 (s, $1 \mathrm{H}), 7.33$ (dd, $J=8.0,16.3 \mathrm{~Hz}, 4 \mathrm{H}), 4.76-4.71(\mathrm{~m}, 2 \mathrm{H}), 4.50(\mathrm{t}$, $J=6.9 \mathrm{~Hz}, 1 \mathrm{H}), 4.42(\mathrm{~d}, J=6.1 \mathrm{~Hz}, 2 \mathrm{H}), 3.97(\mathrm{~d}, J=11.8 \mathrm{~Hz}, 1 \mathrm{H})$, 3.74-3.69 (m, $1 \mathrm{H}), 3.62(\mathrm{~s}, 3 \mathrm{H}), 2.54-2.37(\mathrm{~m}, 6 \mathrm{H}), 2.24(\mathrm{t}, J=7.6 \mathrm{~Hz}$, $2 \mathrm{H}), 2.21-2.16(\mathrm{~m}, 1 \mathrm{H}), 1.67-1.58(\mathrm{~m}, 2 \mathrm{H}), 1.52-1.42(\mathrm{~m}, 2 \mathrm{H})$, 1.32-1.24 (m, 10H); ${ }^{13} \mathrm{C}$ NMR $\delta:\left(101 \mathrm{MHz}, \mathrm{CDCl}_{3}\right) \delta 173.8,170.9$, $170.5\left(\mathrm{~d},{ }^{2} J=20.7 \mathrm{~Hz}\right), 170.0,150.5,148.6,138.2,131.7,131.1$, 129.6, 128.2, 79.4, 70.2, 59.2, 56.7, 56.2, 51.7, 48.1, 43.2, 36.9, 33.6, 28.9, 28.0, 25.8, 25.4, 24.4, 16.1, $14.0\left(\mathrm{~d},{ }^{2} J=3.4 \mathrm{~Hz}\right), 13.9$ (d, ${ }^{2} J=3.4 \mathrm{~Hz}$ ). MS: calculated for $\mathrm{C}_{31} \mathrm{H}_{42} \mathrm{FN}_{4} \mathrm{O}_{6} \mathrm{~S}_{2}[\mathrm{M}+\mathrm{H}]^{+}: \mathrm{m} /$ $z=649.3$; observed: $m / z=649.3$.

\subsubsection{3. $(2 S, 4 R)-1-((2 R)-3-((4-((2-)(2-(2,6-$ dioxopiperidin-3-yl)-1,3-} dioxoisoindolin-4-yl)amino)ethyl)amino)-4-oxobutyl)thio)-2-(1fluorocyclopropane-1-carboxamido)-3-methylbutanoyl)-4-hydroxy- $N$-(4(4-methylthiazol-5-yl)benzyl)pyrrolidine-2-carboxamide (22c)

Compound 21c ( $16.5 \mathrm{mg}, 0.025 \mathrm{mmol}, 1$ eq.) was dissolved in a mixture of THF $(1 \mathrm{~mL})$ and water $(0.25 \mathrm{~mL})$. Then $\mathrm{LiOH}$ was added $(1.2 \mathrm{mg}, 0.0509 \mathrm{mmol}, 2 \mathrm{eq}$.) and the mixture was stirred at r.t. for $2 \mathrm{~h}$. LC-MS analysis (acidic method) showed complete conversion of the starting material. A solution of $\mathrm{HCl} 4 \mathrm{~N}$ in dioxane was added to $\mathrm{pH}<6$ and the mixture was evaporated to dryness to yield the deprotected carboxylic acid derivative (16.1 mg, yield: quantitative). Starting from the crude carboxylic acid $(0.025 \mathrm{mmol}, 1$ eq.) and following the general method $\mathbf{H}$, the desired compound was obtained (9.2 mg, yield: 39\%). ${ }^{1} \mathrm{H}$ NMR (500 MHz, MeOD) $\delta: 8.92$ (s, 1H), 7.54 (dd, $J=7.2,8.5 \mathrm{~Hz}, 1 \mathrm{H}), 7.46-7.39(\mathrm{~m}, 4 \mathrm{H}), 7.07$ (dd, $J=7.8$, $23.5 \mathrm{~Hz}, 2 \mathrm{H}), 5.04$ (dd, $J=5.6,12.9 \mathrm{~Hz}, 1 \mathrm{H}), 4.91(\mathrm{~d}, J=9.2 \mathrm{~Hz}, 1 \mathrm{H})$, $4.61(\mathrm{t}, J=8.3 \mathrm{~Hz}, 1 \mathrm{H}), 4.53-4.36(\mathrm{~m}, 3 \mathrm{H}), 3.90-3.82(\mathrm{~m}, 2 \mathrm{H})$, $3.48-3.37$ (m, 4H), 2.89-2.68 (m, 3H), 2.56 (t, $J=7.4 \mathrm{~Hz}, 2 \mathrm{H}), 2.48$ (s, $3 \mathrm{H}), 2.29-2.22(\mathrm{~m}, 1 \mathrm{H}), 2.14-2.08(\mathrm{~m}, 4 \mathrm{H}), 1.67-1.55(\mathrm{~m}, 2 \mathrm{H})$, 1.51-1.43 (m, 2H), 1.41-1.25 (m, 10H); ${ }^{13} \mathrm{C}$ NMR (126 MHz, MeOD) $\delta$ : 176.4, 174.6, 174.1, 171.5, 170.9, 170.6, 169.3, 153.0, 148.7, 148.2, $140.3,137.2$, 134.0, 133.6, 131.4, 130.5, 130.4, 129.5, 129.0, 118.0, 112.1, 111.5, $79.1\left(\mathrm{~d},{ }^{1} J=232.0 \mathrm{~Hz}\right) 71.0,61.1,58.1,57.3,57.2,43.7$,
42.8, 39.8, 39.0, 36.4, 32.2, 30.2, 29.0, 27.1, 26.2, 25.7, 23.8, 15.7, 14.2, $14.1\left(\mathrm{dd},{ }^{2} J=9.1 \mathrm{~Hz}\right)$. HRMS: calculated for $\mathrm{C}_{45} \mathrm{H}_{53} \mathrm{FN}_{8} \mathrm{O}_{9} \mathrm{~S}_{2}$ $[\mathrm{M}+\mathrm{H}]^{+}: m / z=933.3434$; observed: $m / z=933.3263$.

\subsection{Biology}

\subsubsection{Cell culture}

HeLa (CCL-2) and HEK293 (CRL-1573) cells were purchased from ATCC and cultured in DMEM medium (Gibco) supplemented with $10 \%$ FBS, $100 \mu \mathrm{g} / \mathrm{mL}$ penicillin/streptomycin and L-glutamine. Cells were grown at $37{ }^{\circ} \mathrm{C}$ and $5 \% \mathrm{CO}_{2}$, and were propagated no longer than 30 passages. All cell lines were routinely tested for mycoplasma contamination using MycoAlert kit from Lonza.

\subsubsection{Evaluation of cellular activity of PROTACs}

HeLa $\left(5 \times 10^{5}\right)$ and HEK293 $\left(1 \times 10^{6}\right)$ cells were seeded in standard 6-well plates ( $2 \mathrm{~mL}$ medium) overnight before treatment with compounds at the desired concentration and a final DMSO concentration of $0.1 \% \mathrm{v} / \mathrm{v}$. After the appropriate incubation time, cells were washed with DPBS (Gibco) and lysed using $85 \mu \mathrm{L}$ RIPA buffer (SigmaAldrich) supplemented with cOmplete Mini EDTA-free protease inhibitor cocktail (Roche) and benzonase. Lysates were clarified by centrifugation $\left(20000 \mathrm{~g}, 10 \mathrm{~min}, 4^{\circ} \mathrm{C}\right)$ and the total protein content of the supernatant was quantified using a Bradford colorimetric assay. Samples were prepared using LDS sample buffer (Invitrogen) and equal amounts of total protein.

\subsubsection{Immunoblotting}

Proteins were separated by SDS-PAGE on NuPage 4-12\% Bis-Tris gels and transferred to Amersham Protran 0.45 NC nitrocellulose membranes (GE Healthcare) using wet transfer. Membranes were blocked using $5 \% \mathrm{w} / \mathrm{v}$ milk in Tris-buffered saline (TBS) with $0.1 \%$ Tween-20. Blots were probed using anti-VHL (CST-68547), anti-CRBN (Novus, NBP1-91810) and anti- $\beta$-tubulin hFAB-rhodamine (BioRad, 12004166) primary antibodies, followed by incubation with secondary anti-Rabbit IRDye 800CW (ab216773) or anti-rabbit HRP-conjugated (CST-7074) antibodies. Blots were developed using a Bio-Rad ChemiDoc MP Imaging System or the Amersham ECL Prime western blotting detection kit and Amersham Hyperfilm ECL film, as appropriate. Band quantification was performed using the ImageJ software. Band intensities were normalized to the $\beta$-tubulin loading control and reported as $\%$ of the average $0.1 \%$ DMSO vehicle intensity. Degradation data was plotted and analysed using Prism (Graphpad, version 7). $\mathrm{DC}_{50}$ values (concentration to reach $50 \%$ maximal degradation) were estimated by fitting band intensity against $\log$ [concentration]. Apparent half-life values (time to reach $50 \%$ maximal degradation) were estimated by fitting band intensity against time using a single-phase exponential decay model.

\section{Acknowledgements}

This project has received funding from the European Research Council (ERC) under the European Union's Seventh Framework Programme (FP7/2007 - 2013) as a Starting Grant to A.C. (grant agreement no. ERC-2012-StG-311460 DrugE3CRLs). Drug discovery activities were supported by Wellcome Trust strategic awards to Dundee (094090/Z/10/Z). M.G. and C.M. were funded by $\mathrm{PhD}$ Studentships from the Italian Ministry of Education, University and Research (Miur). We thank S. Imaide for the gift of linker intermediates.

\section{Conflicting Interests}

The Ciulli laboratory receives sponsored research support from Boehringer Ingelheim and Nurix, Inc. A.C. is a scientific founder, director and shareholder of Amphista Therapeutics, a company that is developing targeted protein degradation therapeutic platforms.

Notes

While this manuscript was in advanced stage of preparation, related 
hetero-bifunctional VHL-CRBN PROTACs were published by C. Steinebach et al. Chem. Commun., DOI: 10.1039/C8CC09541H as an Accepted Manuscript, in which preferential degradation of CRBN over VHL was also observed with a compound different from 14a.

\section{Appendix A. Supplementary data}

Supplementary data to this article can be found online at https:// doi.org/10.1016/j.bmc.2019.02.048.

\section{References}

1. Ciechanover A. Intracellular Protein Degradation: From a Vague Idea Through the Lysosome and the Ubiquitin-Proteasome System and Onto Human Diseases and Drug Targeting. Bioorg Med Chem. 2013;21(12):3400-3410.

2. Lai AC, Crews CM. Induced Protein Degradation: an Emerging Drug Discovery Paradigm. Nat Rev Drug Discov. 2017;16(2):101-114.

3. Hughes SJ, Ciulli A. Molecular Recognition of Ternary Complexes: a New Dimension in the Structure-Guided Design of Chemical Degraders. Essays Biochem. 2017;61(5):505-516.

4. Wertz IE, Wang X. From Discovery to Bedside: Targeting the Ubiquitin System. Cell Chem Biol. 2018. https://doi.org/10.1016/j.chembiol.2018.10.022.

5. Sakamoto KM, Kim KB, Kumagai A, Mercurio F, Crews CM, Deshaies RJ. Protacs: Chimeric Molecules That Target Proteins to the Skp1-Cullin-F Box Complex for Ubiquitination and Degradation. P Natl Acad Sci Usa. 2001;98(15):8554-8559.

6. Deshaies RJ. Protein Degradation: Prime Time for PROTACs. Nat Chem Biol. 2015;11(9):634-635.

7. Winter GE, Buckley DL, Paulk J, et al. Phthalimide Conjugation as a Strategy for in Vivo Target Protein Degradation. Science. 2015;348(6241):1376-1381.

8. Zengerle M, Chan K-H, Ciulli A. Selective Small Molecule Induced Degradation of the BET Bromodomain Protein BRD4. ACS Chem Biol. 2015;10(8):1770-1777.

9. Lu J, Qian Y, Altieri M, et al. Hijacking the E3 Ubiquitin Ligase Cereblon to Efficiently Target BRD4. Chem Biol. 2015;22(6):755-763.

10. Bondeson DP, Mares A, Smith IED, et al. Catalytic in Vivo Protein Knockdown by Small-Molecule PROTACs. Nat Chem Biol. 2015;11(8):611-617.

11. Maniaci C, Hughes SJ, Testa A, et al. Homo-PROTACs: Bivalent Small-Molecule Dimerizers of the VHL E3 Ubiquitin Ligase to Induce Self-Degradation. Nat Commun. 2017;8(1):830.

12. Bondeson DP, Smith BE, Burslem GM, et al. Lessons in PROTAC Design From Selective Degradation with a Promiscuous Warhead. Cell Chem Biol. 2018;25(1):78-87.e5.

13. Testa A, Lucas X, Castro GV, et al. 3-Fluoro-4-Hydroxyprolines: Synthesis, Conformational Analysis, and Stereoselective Recognition by the VHL E3 Ubiquitin Ligase for Targeted Protein Degradation. J Am Chem Soc. 2018;140(29):9299-9313.

14. Qin C, Hu Y, Zhou B, et al. Discovery of OCA570 as an Exceptionally Potent and Efficacious Proteolysis Targeting Chimera (PROTAC) Degrader of the Bromodomain and Extra-Terminal (BET) Proteins Capable of Inducing Complete and Durable Tumor Regression. J Med Chem. 2018;61(15):6685-6704.

15. Gadd MS, Testa A, Lucas X, et al. Structural Basis of PROTAC Cooperative Recognition for Selective Protein Degradation. Nat Chem Biol. 2017;13(5):514-521.

16. Brand M, Jiang B, Bauer S, et al. Homolog-Selective Degradation as a Strategy to Probe the Function of CDK6 in AML. Cell Chem Biol. 2018:1-25.

17. Nowak RP, DeAngelo SL, Buckley D, et al. Plasticity in Binding Confers Selectivity in Ligand-Induced Protein Degradation Article. Nat Chem Biol. 2018;14(7):706-714.

18. An S, Fu L. Small-Molecule PROTACs: an Emerging and Promising Approach for the Development of Targeted Therapy Drugs. EBioMedicine. 2018;36:553-562

19. Zou Y, Ma D, Wang Y. The PROTAC Technology in Drug Development. Cell Biochem Funct. 2019;37(1):21-30.

20. Raina K, Lu J, Qian Y, et al. PROTAC-Induced BET Protein Degradation as a Therapy for Castration-Resistant Prostate Cancer. P Natl Acad Sci Usa. 2016;113(26):7124-7129.

21. Chan K-H, Zengerle M, Testa A, Ciulli A. Impact of Target Warhead and Linkage Vector on Inducing Protein Degradation: Comparison of Bromodomain and ExtraTerminal (BET) Degraders Derived From Triazolodiazepine (JQ1) and Tetrahydroquinoline (I-BET726) BET Inhibitor Scaffolds. J Med Chem 2018;61(2):504-513.

22. Remillard D, Buckley DL, Paulk J, et al. Degradation of the BAF Complex Factor BRD9 by Heterobifunctional Ligands. Angew Chem Int Ed Engl. 2017;468:1067.

23. Zoppi V, Hughes SJ, Maniaci C, et al. Iterative Design and Optimization of Initially Inactive Proteolysis Targeting Chimeras (PROTACs) Identify VZ185 as a Potent, Fast, and Selective Von Hippel-Lindau (VHL) Based Dual Degrader Probe of BRD9 and BRD7. J Med Chem. 2019;62(2):699-726.

24. Gechijian LN, Buckley DL, Lawlor MA, et al. Functional TRIM24 Degrader via Conjugation of Ineffectual Bromodomain and VHL Ligands. Nat Chem Biol 2018;168:629.

25. Bassi ZI, Fillmore MC, Miah AH, et al. Modulating PCAF/GCN5 Immune Cell Function Through a PROTAC Approach. ACS Chem Biol. 2018;13(10):2862-2867.

26. An Z, Lv W, Su S, Wu W, Rao Y. Developing Potent PROTACs Tools for Selective Degradation of HDAC6 Protein. Protein Cell. 2019;130:987-994.
27. Robb CM, Contreras JI, Kour S, et al. Chemically Induced Degradation of CDK9 by a Proteolysis Targeting Chimera (PROTAC). Chem Commun (Camb). 2017;53(54):7577-7580

28. Olson CM, Jiang B, Erb MA, et al. Pharmacological Perturbation of CDK9 Using Selective CDK9 Inhibition or Degradation. Nat Chem Biol. 2018;14(2):163-170.

29. Zhang C, Han X-R, Yang X, et al. Proteolysis Targeting Chimeras (PROTACs) of Anaplastic Lymphoma Kinase (ALK). Eur J Med Chem. 2018;151:304-314.

30. Burslem GM, Song J, Chen X, Hines J, Crews CM. Enhancing Antiproliferative Activity and Selectivity of a FLT-3 Inhibitor by Proteolysis Targeting Chimera Conversion. J Am Chem Soc. 2018;140(48):16428-16432.

31. Crew AP, Raina K, Dong H, et al. Identification and Characterization of Von HippelLindau-Recruiting Proteolysis Targeting Chimeras (PROTACs) of TANK-Binding Kinase 1. J Med Chem. 2018:61(2):583-598.

32. Salami J, Alabi S, Willard RR, et al. Androgen Receptor Degradation by the Proteolysis-Targeting Chimera ARCC-4 Outperforms Enzalutamide in Cellular Models of Prostate Cancer Drug Resistance. Commun Biol. 2018;1(1):100.

33. McCoull W, Cheung T, Anderson E, et al. Development of a Novel B-Cell Lymphoma 6 (BCL6) PROTAC to Provide Insight Into Small Molecule Targeting of BCL6. ACS Chem Biol. 2018;13(11):3131-3141.

34. Zhao Q, Lan T, Su S, Rao Y. Induction of Apoptosis in MDA-MB-231 Breast Cancer Cells by a PARP1-Targeting PROTAC Small Molecule. Chem Commun (Camb). 2019;55(3):369-372.

35. Hu J, Hu B, Weng M, et al. Discovery of ERD-308 as a Highly Potent Proteolysis Targeting Chimera (PROTAC) Degrader of Estrogen Receptor (ER). J Med Chem. 2019;62(3):1420-1442

36. Gandhi AK, Kang J, Havens CG, et al. Immunomodulatory Agents Lenalidomide and Pomalidomide Co-Stimulate T Cells by Inducing Degradation of T Cell Repressors Ikaros and Aiolos via Modulation of the E3 Ubiquitin Ligase Complex CRL4(CRBN.). Br J Haematol. 2014;164(6):811-821.

37. Krönke J, Fink EC, Hollenbach PW, et al. Lenalidomide Induces Ubiquitination and Degradation of CK1 $\alpha$ in Del(5q) MDS. Nature. 2015;523(7559):183-188.

38. Neklesa T, Snyder LB, Willard RR, et al. Abstract 5236: ARV-110: an Androgen Receptor PROTAC Degrader for Prostate Cancer. Cancer Res. 2018;78(13 Supplement):5236.

39. Petroski MD, Deshaies RJ. Function and Regulation of Cullin-RING Ubiquitin Ligases. Nat Rev Mol Cell Biol. 2005;6(1):9-20.

40. Buetow L, Huang DT. Structural Insights Into the Catalysis and Regulation of E3 Ubiquitin Ligases. Nat Rev Mol Cell Biol. 2016;17(10):626-642.

41. Zheng N, Shabek N. Ubiquitin Ligases: Structure, Function, and Regulation. Annu Rev Biochem. 2017;86:129-157.

42. Hoeller D, Dikic I. Targeting the Ubiquitin System in Cancer Therapy. Nature. 2009;458(7237):438-444.

43. Skaar JR, Pagan JK, Pagano M. SCF Ubiquitin Ligase-Targeted Therapies. Nat Rev Drug Discov. 2014;13(12):889-903.

44. Senft D, Qi J, Ronai ZA. Ubiquitin Ligases in Oncogenic Transformation and Cancer Therapy. Nat Rev Cancer. 2018;18(2):69-88.

45. Vu B, Wovkulich P, Pizzolato G, et al. Discovery of RG7112: a Small-Molecule MDM2 Inhibitor in Clinical Development. ACS Med Chem Lett. 2013;4(5):466-469.

46. Soares P, Gadd MS, Frost J, et al. Group-Based Optimization of Potent and Cell-Active Inhibitors of the Von Hippel-Lindau (VHL) E3 Ubiquitin Ligase: Structure-Activity Relationships Leading to the Chemical Probe (2S,4R)-1-((S)-2-(1-

Cyanocyclopropanecarboxamido)-3,3-Dimethylbutanoyl)-4-Hydroxy-N-(4-(4Methylthiazol-5-Yl)Benzyl)Pyrrolidine-2-Carboxamide (VH298). J Med Chem. 2018;61(2):599-618.

47. Cai Q, Sun H, Peng Y, et al. Potent and Orally Active Antagonist (SM-406/at-406) of Multiple Inhibitor of Apoptosis Proteins (IAPS) in Clinical Development for Cancer Treatment. 2011;54(8):2714-2726.

48. Bulatov E, Ciulli A. Targeting Cullin-RING E3 Ubiquitin Ligases for Drug Discovery: Structure Assembly and Small-Molecule Modulation. Biochem J. 2015;467(3):365-386.

49. Lucas X, Ciulli A. Recognition of Substrate Degrons by E3 Ubiquitin Ligases and Modulation by Small-Molecule Mimicry Strategies. Curr Opin Struct Biol. 2017;44:101-110

50. Frost J, Galdeano C, Soares P, et al. Potent and Selective Chemical Probe of Hypoxic Signalling Downstream of HIF-A Hydroxylation via VHL Inhibition. Nat Commun. 2016;7:13312.

51. Lopez-Girona A, Mendy D, Ito T, et al. Cereblon Is a Direct Protein Target for Immunomodulatory and Antiproliferative Activities of Lenalidomide and Pomalidomide. Leukemia. 2012;26(11):2326-2335.

52. Stewart AK. Medicine. How Thalidomide Works Against Cancer. Science. 2014;343(6168):256-257.

53. Uehara T, Minoshima Y, Sagane K, et al. Selective Degradation of Splicing Factor CAPERa by Anticancer Sulfonamides. Nat Chem Biol. 2017;13(6):675-680.

54. Han T, Goralski M, Gaskill N, et al. Anticancer Sulfonamides Target Splicing by Inducing RBM39 Degradation via Recruitment to DCAF15. Science. 2017 356:6336:eaal3755.

55. Steinebach C, Lindner S, Udeshi ND, et al. Homo-PROTACs for the Chemical Knockdown of Cereblon. ACS Chem Biol. 2018;13(9):2771-2782.

56. Ciulli A, Maniaci C, Hughes SJ, Testa A. Small molecules. Patent WO/2018/189554 2018.

57. Galdeano C, Gadd MS, Soares P, et al. Structure-Guided Design and Optimization of Small Molecules Targeting the Protein-Protein Interaction Between the Von HippelLindau (VHL) E3 Ubiquitin Ligase and the Hypoxia Inducible Factor (HIF) Alpha 
Subunit with in Vitro Nanomolar Affinities. J Med Chem. 2014;57(20):8657-8663.

58. Shahbazi S, Peer CJ, Polizzotto MN, et al. A Sensitive and Robust HPLC Assay with Fluorescence Detection for the Quantification of Pomalidomide in Human Plasma for Pharmacokinetic Analyses. J Pharm Biomed Anal. 2014;92:63-68.

59. Li Y, Yang J, Aguilar A, et al. Discovery of MD-224 as a First-in-Class, Highly Potent, and Efficacious Proteolysis Targeting Chimera Murine Double Minute 2 Degrader Capable of Achieving Complete and Durable Tumor Regression. J Med Chem.
2019;62(2):448-466

60. Steinebach C, Kehm H, Lindner S, et al. PROTAC-Mediated Crosstalk Between E3 Ligases. Chem Commun (Camb). 2019;55(12):1821-1824.

61. Wittmann V, Takayama S, Gong KW, Weitz-Schmidt G, Wong C-H. Ligand Recognition by E- and P-Selectin: Chemoenzymatic Synthesis and Inhibitory Activity of Bivalent Sialyl Lewis X Derivatives and Sialyl Lewis X Carboxylic Acids. J Org Chem. 1998;63(15):5137-5143. 